\title{
Effects of Lysophosphatidylcholine on Electrophysiological Properties and Excitation-Contraction Coupling in Isolated Guinea Pig Ventricular Myocytes
}

Edwin Liu, Joshua I. Goldhaber, and James N. Weiss

Division of Cardiology and the UCLA Cardiovascular Research Laboratory, UCLA School of Medicine, Los Angeles, California 90024

\begin{abstract}
Lysophosphoglyceride accumulation in ischemic myocardium has been implicated as a cause of arrhythmias. We examined the effects of lysophosphatidylcholine (LPC) in isolated guinea pig ventricular myocytes. In paced myocytes loaded with the $\mathrm{Ca}^{2+}$ indicator Indo-1-AM and studied at room temperature, 20 $\mu M$ LPC caused an initial positive inotropic effect followed by spontaneous automaticity, a decline in active cell shortening, and progressive diastolic shortening (contracture) leading to cell death. These changes were accompanied by a progressive increase in cytosolic $\left[\mathrm{Ca}^{2+}\right]_{\mathrm{i}}$. In patch-clamped myocytes dialyzed internally with high EGTA concentrations, LPC caused membrane depolarization, shortening of the action potential duration, and abnormal automaticity as seen in multicellular preparations. Voltage clamp experiments revealed the appearance of a nonselective leak conductance without significant changes in the delayed rectifier $\mathrm{K}^{+}$current, inward rectifier $\mathrm{K}^{+}$current, L-type $\mathrm{Ca}^{2+}$ current, and T-type $\mathrm{Ca}^{2+}$ current. Pretreatment with $20 \mathrm{mM}$ caffeine and $\left[\mathrm{Ca}^{2+}\right]_{0}$-free solution did not prevent the leak current. In patch clamped myocytes loaded with 0.1 mM Fura-2 salt, the $\left[\mathrm{Ca}^{2+}\right]$, transient induced by either voltage clamps or brief caffeine exposure remained normal until the nonselective leak current developed. The $\mathrm{Na}^{+}-\mathrm{Ca}^{2+}$ exchange current elicited during caffeine-induced $\left[\mathrm{Ca}^{2+}\right]$ transients also did not appear to be altered by LPC. Qualitatively similar results were obtained in myocytes studied at $35^{\circ} \mathrm{C}$. The membrane detergent saponin $(0.005 \% \mathrm{wt} / \mathrm{wt})$ mimicked all of the effects of LPC. We conclude that under these experimental conditions the effects of LPC are most compatible with a detergent action causing membrane leakiness with resultant depolarization, $\left[\mathrm{Ca}^{2+}\right]_{\mathrm{h}}$ overload, and contracture. (J. Clin. Invest. 1991. 88:1819-1832.) Key words: arrhythmias • cardiac electrophysiology • cardiac excitation-contraction coupling • ion channels • lysophosphoglycerides • myocardial ischemia
\end{abstract}

\section{Introduction}

Ventricular arrhythmias remain the leading cause of death from coronary artery disease. Accumulation of metabolites during conditions of low coronary flow may play an important role in producing the electrophysiological alterations that lead to the development of lethal ischemic arrhythmias (3). The alterations in lipid metabolism and increased phospholipid

Portions of this work have been presented in abstract form $(1,2)$.

Address reprint requests to Dr. Weiss, Division of Cardiology, 47.

123 CHS, UCLA School of Medicine, Los Angeles, CA 90024.

Received for publication 11 February 1991 and in revised form 9 July 1991.

\section{J. Clin. Invest.}

(C) The American Society for Clinical Investigation, Inc

$0021-9738 / 91 / 12 / 1819 / 14 \$ 2.00$

Volume 88, December 1991, 1819-1832 breakdown that occur during ischemia (4-6) have focused attention on various lipid metabolites as possible mediators of ventricular dysfunction (for reviews see references 7-10). Lysophosphoglycerides, breakdown products of membrane phospholipids, have in particular been singled out for their arrhythmogenic properties. A considerable number of studies have examined the production, accumulation, and electrophysiological effects of these amphiphiles on the myocardium (for reviews see references 9-12). In intact ventricular muscle and Purkinje fibers, electrophysiological effects of lysophosphoglycerides include decreases in diastolic resting potential, action potential amplitude and duration, and the appearance of abnormal automaticity, delayed afterdepolarizations, and triggered activity (13-18). Similar effects have been described in single ventricular myocytes $(19,20)$. Many of these effects are suggestive of intracellular $\mathrm{Ca}^{2+}$ overload, and Sedlis et al. (21, 22) showed that lysophosphoglycerides induced an increase in total intracellular $\mathrm{Ca}^{2+}$ measured with ${ }^{45} \mathrm{Ca}^{2+}$. Direct electrophysiological effects of lysophosphoglycerides have also been described. In voltage-clamped cat papillary muscles, Clarkson and Ten Eick (14) attributed the decrease in resting potential to a decrease in the background $\mathrm{K}^{+}$current and the decrease in action potential amplitude to a decrease in the slow inward $\mathrm{Ca}^{2+}$ current. They also found an increase in twitch tension which they could not account for. In single guinea pig ventricular myocytes studied with the patch clamp technique, Kiyosue et al. $(19,20)$ demonstrated a decrease in both the macroscopic and unitary currents through inward rectifier $\mathrm{K}^{+}$channels, although there was no change in the L-type $\mathrm{Ca}^{2+}$ current. In isolated membrane patches from guinea pig ventricular myocytes the lysophosphoglyceride lysophosphatidylcholine (LPC) ${ }^{1}$ altered $\mathrm{Na}^{+}$channel inactivation (23) and suppressed ATP-sensitive $\mathrm{K}^{+}$channels (24).

In this study, we have investigated further the effects of LPC in single guinea pig ventricular cells using the whole-cell configuration of the patch clamp technique and intracellular $\mathrm{Ca}^{2+}$ indicators in order to further elucidate the mechanisms underlying lysophosphoglyceride-induced electrophysiologic derangements. The results suggest that LPC at a concentration of $20 \mu \mathrm{M}$ acts primarily as a detergent, inducing a nonselective leak current causing membrane depolarization. This leak current appeared to be the cause rather than the result of intracellular $\mathrm{Ca}^{2+}$ overload. No primary effects of LPC on the individual membrane currents and processes regulating intracellular $\mathrm{Ca}^{2+}$ homeostasis which we investigated were detected.

\section{Methods}

Cell isolation and patch clamp methods. Single ventricular myocytes were prepared from adult guinea pigs weighing 250-300 g using the

1. Abbreviations used in this paper: $\mathrm{CCD}$, charge-coupled device; $I_{\mathrm{Ca}, \mathrm{L}}$ L-type $\mathrm{Ca}^{2+}$ current; $I_{\mathrm{C}, \mathrm{T}}, \mathrm{T}$-type $\mathrm{Ca}^{2+}$ current; $I_{\mathrm{K}}$, delayed rectifier $\mathrm{K}^{+}$ current; $I_{\mathrm{K} 1}$, inward rectifier $\mathrm{K}^{+}$current; LPC, lysophosphatidylcholine; TTX, tetrodotoxin. 
method of Mitra and Morad (25). Whole-cell currents were recorded using the gigaseal patch clamp technique (26) with fire-polished patch electrodes pulled from no. 8161 glass (Corning Glass Inc., Corning, NY) and mounted to the headstage of either a model EPC-7 (List Biological Laboratories Inc., Campbell, CA) or Axopatch model 1C (Axon Instruments, Inc., Burlingame, CA) patch-clamp amplifier. Patch electrode tip resistances ranged from 0.5 to $2.0 \mathrm{M} \Omega$. Current and voltage step commands were given to the amplifier via an 80286-based microcomputer using an Axolab 1100 data acquisition and analysis system with PCLAMP software (Axon Instruments, Inc.). Capacitance compensation and series resistance compensation were both employed. In some experiments, myocytes were field-stimulated by passing 5-ms 5-10-V square voltage pulses between a pair of platinum electrodes immersed in the experimental chamber, using a stimulator (Grass Instrument Co., Quincy, MA). Data were recorded directly to hard disc by the computer and displayed simultaneously on a storage oscilloscope and chart recorder. In some experiments, data and the video image of the cell were also recorded on a modified videocasette recorder (model 420, A.R. Vetter Co., Rebersburg, PA). Cells were placed in a $0.5-\mathrm{ml}$ chamber mounted on the stage of a Nikon Diaphot inverted microscope (A. G. Heinze \& Co., Irvine, CA) and continuously perfused throughout the experiment at $1-4 \mathrm{ml} / \mathrm{min}$. Most experiments were performed at room temperature $\left(20-25^{\circ} \mathrm{C}\right)$. In experiments performed at $35^{\circ} \mathrm{C}\left( \pm 1^{\circ} \mathrm{C}\right)$, a water-jacketing system was used to preheat the solutions entering the bath, and the chamber was warmed from below through a heated aluminum plate. In most experiments, the standard bath solution consisted of (in millimolar): 136 $\mathrm{NaCl}, 5.4 \mathrm{KCl}, 0.33 \mathrm{NaH}_{2} \mathrm{PO}_{4}, 1 \mathrm{MgCl}_{2}, 1.8 \mathrm{CaCl}_{2}, 10$ glucose, and 10 Hepes, $\mathrm{pH}$ adjusted to 7.4 with $\mathrm{NaOH}$. L- $\alpha$-Lysophosphatidylcholine palmitoyl (LPC; 5,20 , or $40 \mu \mathrm{M})$ and saponin $(0.005 \% \mathrm{wt} / \mathrm{wt})$ were obtained from Sigma Chemical Co., St. Louis, MO, and were dissolved directly in the bath solution. The standard patch electrode filling solution contained (in millimolar): $150 \mathrm{KCl}+\mathrm{KOH}, 10 \mathrm{NaCl}, 14 \mathrm{EGTA}, 1$ $\mathrm{CaCl}_{2}, 1 \mathrm{MgCl}_{2}, 10$ Hepes, and $4 \mathrm{MgATP} ; \mathrm{pH}$ 7.4. $5 \mathrm{mM}$ phosphocreatine was also included in some experiments. In some experiments $\mathrm{KCl}$ was replaced with equimolar $\mathrm{K}^{+}$glutamate. For experiments examining $\mathrm{T}$ - and $\mathrm{L}$-type $\mathrm{Ca}^{2+}$ currents, $\mathrm{Na}^{+}$and $\mathrm{K}^{+}$currents were suppressed using a bath solution consisting of (in millimolar): $145 \mathrm{CsCl}+\mathrm{CsOH}, 5$ $\mathrm{CaCl}_{2}, 0.33 \mathrm{NaH}_{2} \mathrm{PO}_{4}, 10$ Hepes, 10 glucose, and 0.001 tetrodotoxin (TTX), pH 7.4; and an internal solution consisting of (in millimolar): $145 \mathrm{CsCl}+\mathrm{CsOH}, 5 \mathrm{NaCl}, 1 \mathrm{CaCl}_{2}, 14$ EGTA, 20 Hepes, $4 \mathrm{MgATP}$; pH 7.4.

For experiments using Fura-2, the internal solution consisted of (in millimolar): $30 \mathrm{KCl}, 95 \mathrm{CsCl}, 5 \mathrm{CsOH}, 10$ tetraethylammonium chloride, 10 Hepes, $5 \mathrm{Na}^{+}$pyruvate, $1 \mathrm{KH}_{2} \mathrm{PO}_{4}, 1 \mathrm{~K}^{+} \mathrm{ADP}, 1 \mathrm{MgCl}_{2}, 0.1$ cyclic AMP, and $0.1 \mathrm{~K}_{s}$ Fura-2, pH 7.4. Extracellular solution exchange was performed with a rapid perfusion device (27) consisting of a bluntly tapered patch electrode with an inner tip diameter of $\approx 150 \mu \mathrm{m}$. Four stainless steel 25-gauge spinal needles were advanced to within $100 \mu \mathrm{m}$ of the tip and epoxied airtight to the shaft at the other end. Solution flow through each needle was controlled by teflon-lined solenoid valves connecting the device to syringes at adjustable heights above the chamber. The rapid perfusion device was mounted on a micromanipulator at a $60^{\circ}$ vertical angle and positioned within $50-100 \mu \mathrm{m}$ of the cell before forming the cell-attached patch. With a $15-\mathrm{cm}$ hydrostatic pressure, the $90 \%$ exchange time of the bath solution surrounding the myocyte was typically about $100 \mathrm{~ms}$, as assessed from the rate of depolarization of resting membrane potential of current-clamped myocytes in response to increased $\left[\mathrm{K}^{+}\right]_{0}$.

Intracellular $\mathrm{Ca}^{2+}$ measurements. Changes in $\left[\mathrm{Ca}^{2+}\right]_{\mathrm{i}}$ were measured in both patch-clamped myocytes loaded with Fura- $2\left(\mathrm{~K}^{+}\right.$salt, from Molecular Probes, Inc., Eugene, OR) via the patch electrode and in unimpaled field-stimulated myocytes loaded with Indo-1-AM. In the Fura-2 experiments the Nikon Diaphot inverted microscope was modified for dual wavelength excitation and measurement of fluorescence emission as described by Callewaert et al. (28). A collimated light beam from a 100-W mercury arc lamp was passed through a computercontrolled electronic shutter and focused onto a 19-mm scanning mirror driven by an oscillator which deflected the beam alternately at $1,100 \mathrm{~Hz}$ through either a 335- or 405-nm interference filter (20-nm bandwidths) and into the epifluorescence port of the inverted microscope. A long-pass dichroic mirror centered at $430 \mathrm{~nm}$ deflected the beam into a Nikon CF Fluor $40 \times$ oil objective which focused the excitation light onto the cell. Light returning through the objective and dichroic mirror (wavelength $>430 \mathrm{~nm}$ ) passed through a $640-\mathrm{nm}$ short-pass dichroic mirror and was collected by a photomultiplier tube. A pinhole in front of the photomultiplier tube restricted fluorescent light to a $20-\mu \mathrm{m}^{2}$ spot on the myocyte. The signals corresponding to each excitation wavelength were demultiplexed using an amplifier which integrated and sample-held the output of the photomultiplier tube during the time the excitation beam was directed through each filter. The position of the beam was detected by photocells placed just below each filter. The $640-\mathrm{nm}$ dichroic mirror was used to reflect 670 $\mathrm{nm}$ light originating from a light-emitting diode, which illuminated the field of view, into a charge-coupled device (CCD) video camera. The CCD camera transmitted the image of the cell to the cell motion detector and a television screen. Fluorescence signals corresponding to the two excitation wavelengths $\left(F_{335}\right.$ and $\left.F_{405}\right)$, cell length, membrane current, and voltage controlled by the patch clamp amplifier were digitized and stored on computer. From the ratio of the fluorescence signals obtained at these wavelengths, the free cytosolic $\mathrm{Ca}^{2+}$ concentration was calculated using the method of Grynkiewicz et al. (29), according to the equation:

$\left[\mathrm{Ca}^{2+}\right]_{\mathrm{i}}=K_{\mathrm{d}}(\beta)\left[\left(R-R_{\mathrm{EGTA}}\right) /\left(R_{\mathrm{Ca}}-R\right)\right]$

assuming a $K_{\mathrm{d}}$ of $140 \mathrm{nM}$ and where $R=\left(F_{405}-F_{405, \mathrm{bg}}\right) /\left(F_{335}-F_{335, \mathrm{bg}}\right)$ and $\beta=F_{335, \text { EGTA }} / F_{335, \mathrm{Ca}}$. The background fluorescences $F_{335, \mathrm{bg}}$ and $F_{405, \text { bg }}$ were measured after forming the cell-attached patch before breaking into the cell. Most of the background fluorescence was due to scatter from the Fura- 2 in the patch electrode and cell motion had no significant effect on the magnitude of background fluorescence. $\boldsymbol{R}_{\mathrm{EGTA}}$ and $R_{\mathrm{Ca}_{\mathrm{a}}}$ averaged 5.26 and 0.04 , respectively, when obtained by measuring the ratios of $F_{405} / F_{335}$ from a thin layer of standard internal solution containing $100 \mu \mathrm{M}$ Fura-2 and either $10 \mathrm{mM}$ EGTA or $2 \mathrm{mM}$ $\mathrm{Ca}^{2+}$ placed on the stage of the microscope. Similar values were obtained with 1 or $10 \mu \mathrm{M}$ Fura-2 instead of $100 \mu \mathrm{M}$.

Indo-1 fluorescence was monitored in field-stimulated myocytes. In most of the LPC experiments performed at room temperature, myocytes were incubated at room temperature for $30 \mathrm{~min}$ in standard bath solution containing $10 \mu \mathrm{M}$ Indo-1-AM (Molecular Probes, Inc.), diluted directly from a stock solution in dimethyl sulfoxide. In the LPC experiments at $35^{\circ} \mathrm{C}$ and the saponin experiments, myocytes were incubated in bath solution containing $5 \mu \mathrm{M}$ Indo-1-AM and $0.016 \%$ (wt/ wt) Pluronic F-127 for $10 \mathrm{~min}$. After either loading period, myocytes were then washed three times with standard bath solution and left for at least $15 \mathrm{~min}$ before use to allow the cells to deesterify intracellular Indo-1-AM as fully as possible. Qualitative results were similar for both methods of loading. To measure epifluorescence, the collimated light beam from a 100 -w mercury arc lamp (Nikon) was passed through an electromechanical shutter triggered by the computer, through a 365 . $\mathrm{nm}$ interference filter, and reflected off a 380-nm long-pass dichroic mirror into a Nikon CF Fluor $40 \times$ oil objective, where it was focused onto a $20-\mu \mathrm{m}$ diam spot over which the myocyte was positioned. Wavelengths $>380 \mathrm{~nm}$ collected by the objective passed through the $380-\mathrm{nm}$ dichroic mirror and were then reflected by a $640-\mathrm{nm}$ long-pass dichroic mirror into a 440-nm long-pass dichroic mirror. This mirror reflected wavelengths $<440 \mathrm{~nm}$ through a $405-\mathrm{nm}$ interference filter (bandwidth $33 \mathrm{~nm}$ ) into the first photomultiplier tube, and wavelengths $>440 \mathrm{~nm}$ through a $495-\mathrm{nm}$ interference filter (bandwidth $20 \mathrm{~nm}$ ) into a second photomultiplier tube. The $640-\mathrm{nm}$ dichroic mirror was used to pass $>640-\mathrm{nm}$ light originating from the halogen lamp of the microscope (filtered with a long-pass RG 695 glass filter [Schott Corp., Yonkers, NY] before reaching the field of view) into a CCD video camera which sent the image of the cell to the cell motion detector and television screen. Because of the inherent difficulties in quantitating 
absolute values of $\left[\mathrm{Ca}^{2+}\right]$ with the Indo-1-AM method, the results are reported as changes in the ratio of fluorescence at 405 and $495 \mathrm{~nm}$, a qualitative measure which is sufficient for assessing relative changes in $\left[\mathrm{Ca}^{2+}\right]_{\mathrm{i}}$ (Eq. 1).

Cell shortening measurements. For experiments in which cell shortening was measured, a video motion detector modified from the design of Steadman et al. (30) was used. The system detects the position of the brightness change corresponding to the edge of the cell along any selectable raster line of the CCD video camera (every $16.7 \mathrm{~ms}$ ) and converts this to a voltage signal. The signal was digitized and acquired simultaneously with current and fluorescence measurements as well as recorded continuously on a chart recorder and modified videocasette recorder.

Data analysis. All data are expressed as the mean \pm 1 SEM. Statistical significance was evaluated using Students' paired and unpaired $t$ tests, with a $P$ value of $<0.05$ considered to indicate a significant difference.

\section{Results}

Effects of $\mathrm{LPC}$ on $\left[\mathrm{Ca}^{2+}\right]_{i}$ and cell shortening. Fig. 1 illustrates the typical effects of LPC on the intracellular $\mathrm{Ca}^{2+}$ transient and cell shortening in two guinea pig ventricular myocytes (at room temperature and $35^{\circ} \mathrm{C}$, respectively) loaded with Indo-1$\mathrm{AM}$ and field-stimulated at $0.2 \mathrm{~Hz}$. LPC caused a transient increase in the amplitude of cell shortening which was associated with increases in both diastolic and systolic $\left[\mathrm{Ca}^{2+}\right]_{i}$, as estimated from the increase in the ratio of cell fluorescence at
405 to $495 \mathrm{~nm}\left(F_{405} / F_{495}\right)$. Subsequently spontaneous contractile activity developed leading to progressive diastolic cell shortening (contracture) and ultimately cell death as diastolic $\left[\mathrm{Ca}^{2+}\right]_{i}$ continued to rise, eventually exceeding the control systolic level. Fig. 2 summarizes the changes in fluorescence ratio $F_{405} /$ $F_{495}$ in a total of 21 myocytes exposed to $20 \mu \mathrm{M} \mathrm{LPC}$ at room temperature and 5 myocytes at $35^{\circ} \mathrm{C}$. In the myocytes studied at room temperature, control diastolic and systolic values of $F_{405} / F_{495}$ were $1.11 \pm 0.04$ and $1.34 \pm 0.05$, respectively. After addition of LPC, diastolic and systolic values increased respectively by $5.0 \pm 1.5 \%$ and $4.2 \pm 1.4 \%$ during positive inotropy, by $13.7 \pm 2.7 \%$ and $4.6 \pm 1.5 \%$ at the onset of spontaneous activity, and by $30.0 \pm 5.0 \%$ and $12.6 \pm 2.4 \%$ during contracture. The transient-positive inotropic phase was observed in 12 of 21 cells and averaged $29.4 \pm 7.0 \%$, whereas all of the myocytes developed spontaneous activity and progressive contracture leading inevitably to cell death. Qualitatively similar results were obtained in the myocytes studied at $35^{\circ} \mathrm{C}$. Four of five showed a transient inotropic response averaging $93.1 \pm 21.0 \%$. Control diastolic and systolic values of $F_{405} / F_{495}$ (using a different loading technique) were $2.41 \pm 0.12 \%$ and $3.42 \pm 0.17 \%$, respectively, and increased by $9.9 \pm 2.6 \%$ and $8.4 \pm 3.2 \%$ during inotropy, $27.4 \pm 4.3 \%$ and $17.2 \pm 4.2 \%$ at the onset of spontaneous activity, and $67.3 \pm 12.5 \%$ and $26.2 \pm 4.2 \%$ during contracture.

In nine field-stimulated myocytes which were not loaded with Indo-1-AM to avoid any perturbation of the normal cytosolic environment, cell shortening was monitored during expo-
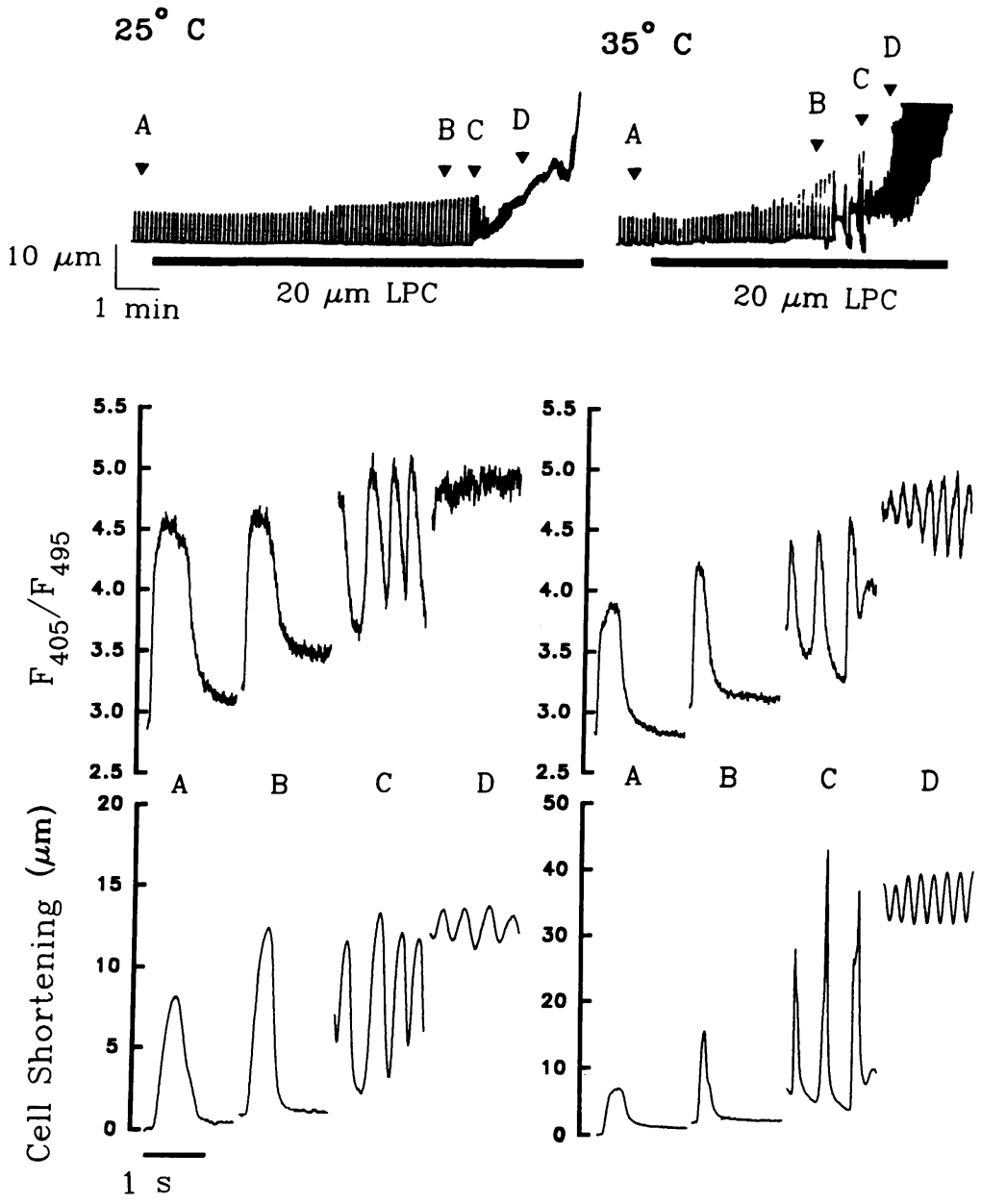

Figure 1. Effects of $20 \mu \mathrm{M} \mathrm{LPC}$ on $\left[\mathrm{Ca}^{2+}\right]_{\mathrm{i}}$ transients and cell shortening in two representative Indo-1AM-loaded myocytes paced at $0.2 \mathrm{~Hz}$, at $25^{\circ} \mathrm{C}$ and $35^{\circ} \mathrm{C}$. Top tracings: Continuous recording of cell shortening during exposure to LPC, demonstrating transient-positive inotropy $(B)$, spontaneous contractile activity and progressive contracture $(C$ and $D)$ leading to cell death. Middle tracings: Measurements of the ratio $\left(F_{405} / F_{495}\right)$ of cell fluorescence at 405 and 495-nm wavelengths (excitation at $360 \mathrm{~nm}$ ) indicating qualitative changes in $\left[\mathrm{Ca}^{2+}\right]_{i}$ during paced beats at the representative points $A-D$ as indicated above. Lower tracings: Cell shortening associated with the $\left[\mathrm{Ca}^{2+}\right]_{\mathrm{i}}$ transients at points $A-D$. 

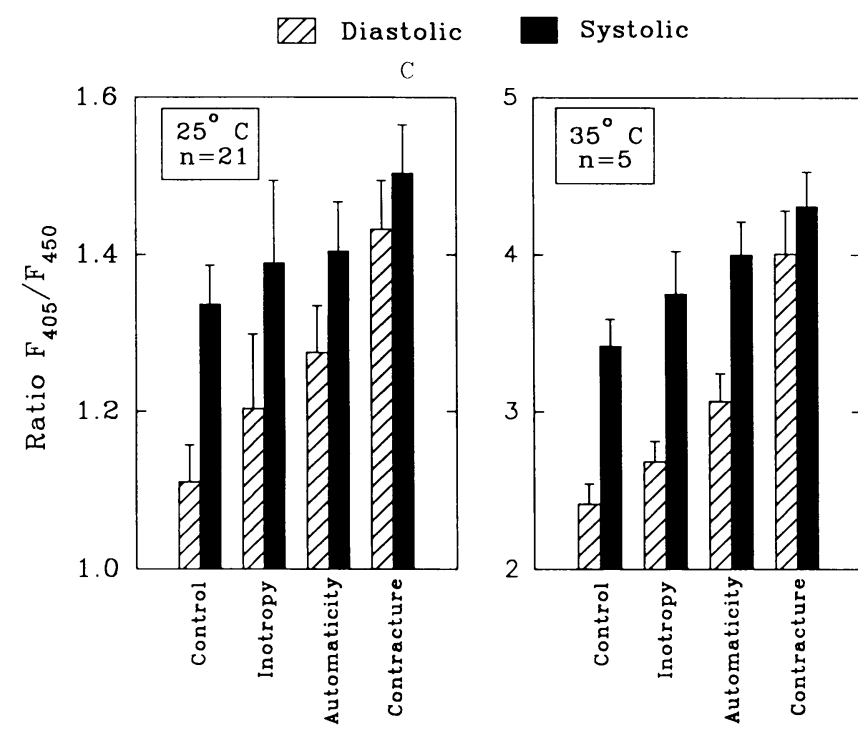

Figure 2. Summary of the effects of $20 \mu \mathrm{M} \mathrm{LPC}$ on the $\left[\mathrm{Ca}^{2+}\right]_{\mathrm{i}}$ transient estimated from changes in the ratio $\left(F_{405} / F_{495}\right)$ of cell fluorescence at $405-$ and $495-\mathrm{nm}$ wavelengths in Indo-1-AM-loaded cells paced at $0.3 \mathrm{~Hz}$, at $25^{\circ} \mathrm{C}$ (left graph) and at $35^{\circ} \mathrm{C}$ (right graph). Mean values $\pm 1 \mathrm{SEM}$ of $F_{405} / F_{495}$ are shown during diastole (cross-hatched bars) and systole (solid bars) under control conditions, during the transient-positive inotropic response, at the onset of automaticity, and during contracture.

sure to LPC at room temperature using the same protocol. Six of nine cells had a transient-positive inotropic response averaging $38.6 \pm 6.4 \%$ and all developed spontaneous activity and pro- gressive contracture leading to cell death, similar to the Indo-1AM-loaded cells.

Effects of LPC on the action potential. To characterize the electrophysiological basis for the LPC-induced changes in $\left[\mathrm{Ca}^{2+}\right]_{\mathrm{i}}$ and cell motion, membrane potential was monitored in patch-clamped ventricular myocytes in the current clamp mode during exposure to LPC. Fig. 3 shows the effects of 20 $\mu \mathrm{M}$ LPC on the action potential of three representative guinea pig ventricular myocytes, dialyzed with standard internal solution containing $14 \mathrm{mM}$ EGTA (estimated free $\left[\mathrm{Ca}^{2+}\right] \approx 10$ $\mathrm{nM}$ ). In the myocytes studied at room temperature (top and middle panels), LPC often initially caused gradual depolarization of resting membrane potential by $3-5 \mathrm{mV}$, which was associated with shortening of the action potential duration (left panels). After an average of $7.5 \pm 0.8 \mathrm{~min}(n=4)$, all of the cells then rapidly and usually abruptly depolarized with concomitant appearance of spontaneous automaticity, leading to complete membrane depolarization and cell death within several minutes (middle and right panels). Because of the high degree of cytosolic $\mathrm{Ca}^{2+}$ buffering by EGTA, none of these electrophysiological derangements were associated with active contractions, but eventually the cells shortened irreversibly in response to severe depolarization. Once the rapid phase of membrane depolarization occurred the effects of LPC were irreversible. Qualitatively similar results were obtained in four myocytes exposed to $20 \mu \mathrm{M} \mathrm{LPC}$ at $35^{\circ} \mathrm{C}$, as illustrated in the lower panels of Fig. 3 .

To rule out the possibility that the abrupt depolarization seen in the above experiments was due to the patch electrode seal becoming leaky, we directly measured the seal resistance of cell-attached patches on myocytes during exposure to LPC, using the same size patch electrodes and internal solution. Ini-

$$
25^{\circ} \mathrm{C}
$$

$20 \mu \mathrm{M} \mathrm{LPC} \quad 0-5 \mathrm{~min}$

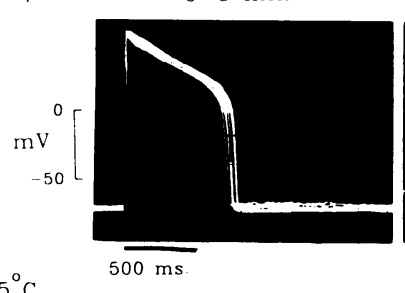

$25^{\circ} \mathrm{C}$

$20 \mu \mathrm{M} \mathrm{LPC} \quad 0-7 \mathrm{~min}$

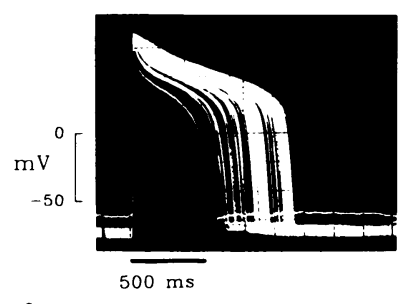

$35^{\circ} \mathrm{C}$
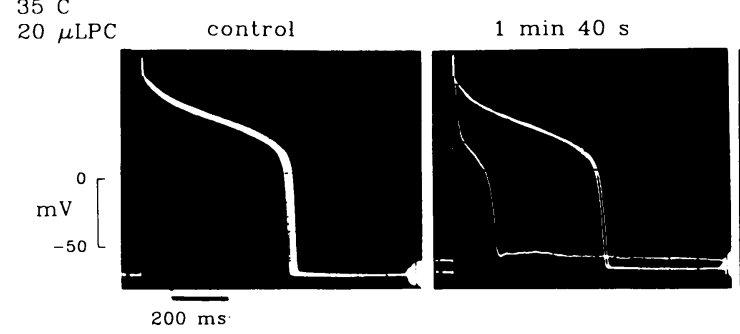

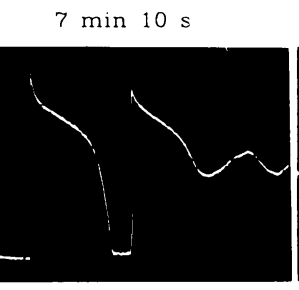

$17 \min$

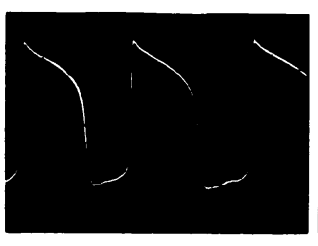

$7 \min 10 \mathrm{~s}$
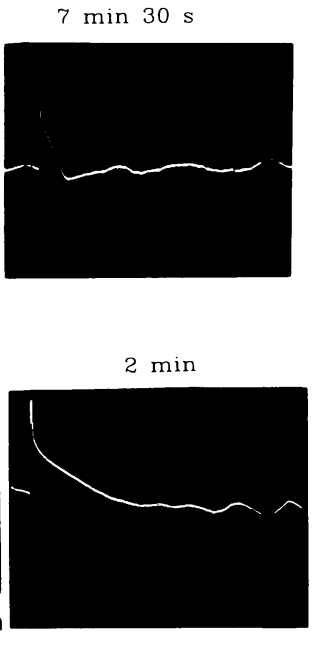

Figure 3. Effects of $20 \mu \mathrm{M}$ LPC on intracellular potential in three representative patch-clamped myocytes stimulated at $0.2 \mathrm{~Hz}$ in the current clamp mode. Upper tracings: In this myocyte at $25^{\circ} \mathrm{C}$, during the first $5 \mathrm{~min}$ of exposure ( first panel), LPC caused slight depolarization of the resting potential and shortening of the action potential duration. After $17 \mathrm{~min}$, the cell depolarized further and spontaneous automaticity occurred (second panel). By $18 \mathrm{~min}$, the resting potential had depolarized further and automaticity continued (third panel). Middle tracings: In another myocyte at $25^{\circ} \mathrm{C}$, resting potential depolarized slightly and the action potential duration shortened progressively during the first 7 min of exposure to LPC ( first panel). The membrane potential then abruptly depolarized and oscillated near $0 \mathrm{mV}$ (second and third panels). Lower tracings: In a myocyte exposed to $\mathrm{LPC}$ at $35^{\circ} \mathrm{C}$, similar changes in membrane potential were observed. The patch electrode solution was highly $\mathrm{Ca}^{2+}$-buffered with $14 \mathrm{mM}$ EGTA in all three myocytes. 
tial seal resistance typically ranged from 5 to $50 \mathrm{G} \Omega$ in different cell-attached patches, and remained stable during superfusion with 20 or $40 \mu \mathrm{M}$ LPC in seven of seven cells even after severe contracture had developed.

At both lower $(5 \mu \mathrm{M})$ and higher $(40 \mu \mathrm{M})$ concentrations, LPC had similar effects on intracellular potential, although the time course differed. At 5, 20, and $40 \mu \mathrm{M}$ LPC, the onset of abrupt membrane depolarization in both current clamp and voltage clamp experiments at room temperature occurred after $18.5(n=1), 8.2 \pm 0.9(n=23)$, and $3.6 \pm 0.71 \mathrm{~min}(n=17)$, respectively. In most experiments we therefore used $20 \mu \mathrm{M}$ LPC, a concentration which was sufficient to see effects within a reasonable time period while allowing enough time to execute the required voltage clamp protocols.

Effects of LPC on membrane currents. The cause of the abrupt membrane depolarization induced by LPC was further studied by examining the effects of LPC on membrane currents in patch-clamped myocytes under voltage-clamp conditions. Fig. 4 (upper traces) shows membrane currents elicited during 400 -ms voltage clamp pulses from a holding potential of -40 $\mathrm{mV}$ to membrane potentials from -100 to $+50 \mathrm{mV}$ (in $10-\mathrm{mV}$ steps) before and after exposure to $20 \mu \mathrm{M} \mathrm{LPC}$ at room temperature. In the graph below, the current-voltage $(I-V)$ relations at $400 \mathrm{~ms}$ are summarized from the averaged data in four cells. The control $I-V$ relation showed the typical $N$-shaped pattern, and did not change significantly for the first $10 \mathrm{~min}$ of superfusion with LPC. After a mean of 13.7 minutes, however, a large time-independent current developed with a reversal potential near $0 \mathrm{mV}$ (see traces). The time-dependent inward current also disappeared, probably due to accelerated rundown of the $\mathrm{Ca}^{2+}$ current.

Fig. 5 illustrates that the early mild depolarization preceding abrupt membrane depolarization was due to activation of a similar current. In this myocyte, resting potential gradually depolarized by $\approx 10 \mathrm{mV}$ during exposure to $20 \mu \mathrm{M} \mathrm{LPC}$ for 11 $\mathrm{min}$. This was caused by an inward shift in the $I-V$ relations $(O$, upper graph) due to the appearance of a time-independent current with a reversal near $0 \mathrm{mV}$ as shown in the difference current $(\mathrm{O}$, lower graph). After $13 \mathrm{~min}$ the myocyte completely depolarized owing to an abrupt increase in the magnitude of the inward current $(\Delta)$, which aside from its larger amplitude had the same characteristics as the earlier current (i.e., time-independent with reversal potential near $0 \mathrm{mV}$ ). The inwardly rectifying $\mathrm{K}^{+}$current did not appear to decrease during membrane depolarization.

At $35^{\circ} \mathrm{C}, 7$ out of 14 myocytes exposed to $20 \mu \mathrm{M} \mathrm{LPC} \mathrm{(Fig.}$ 6 , upper graph) showed similar changes in the $I-V$ relations as the myocytes studied at room temperature, although the time to onset of the large inward current was shorter, averaging $2.9 \pm 0.6 \mathrm{~min}$. In the other seven myocytes, however, LPC caused a large time-independent $\mathrm{K}^{+}$current to appear (middle graph). In two of these myocytes a later series of voltage clamps (not repeated in the other myocytes) showed that the $\mathrm{K}^{+}$ current was replaced by the typical large nonselective current. The $\mathrm{K}^{+}$current was time-independent and did not show much inward or outward rectification, possibly suggesting activation of ATP-sensitive $\mathrm{K}^{+}$channels. Before the development of these currents, the peak inward current was mildly depressed compatible with typical rundown of the L-type $\mathrm{Ca}^{2+}$ current (lower graph).

The reversal potential near $0 \mathrm{mV}$ of the large current induced by LPC is consistent with either a nonselective current

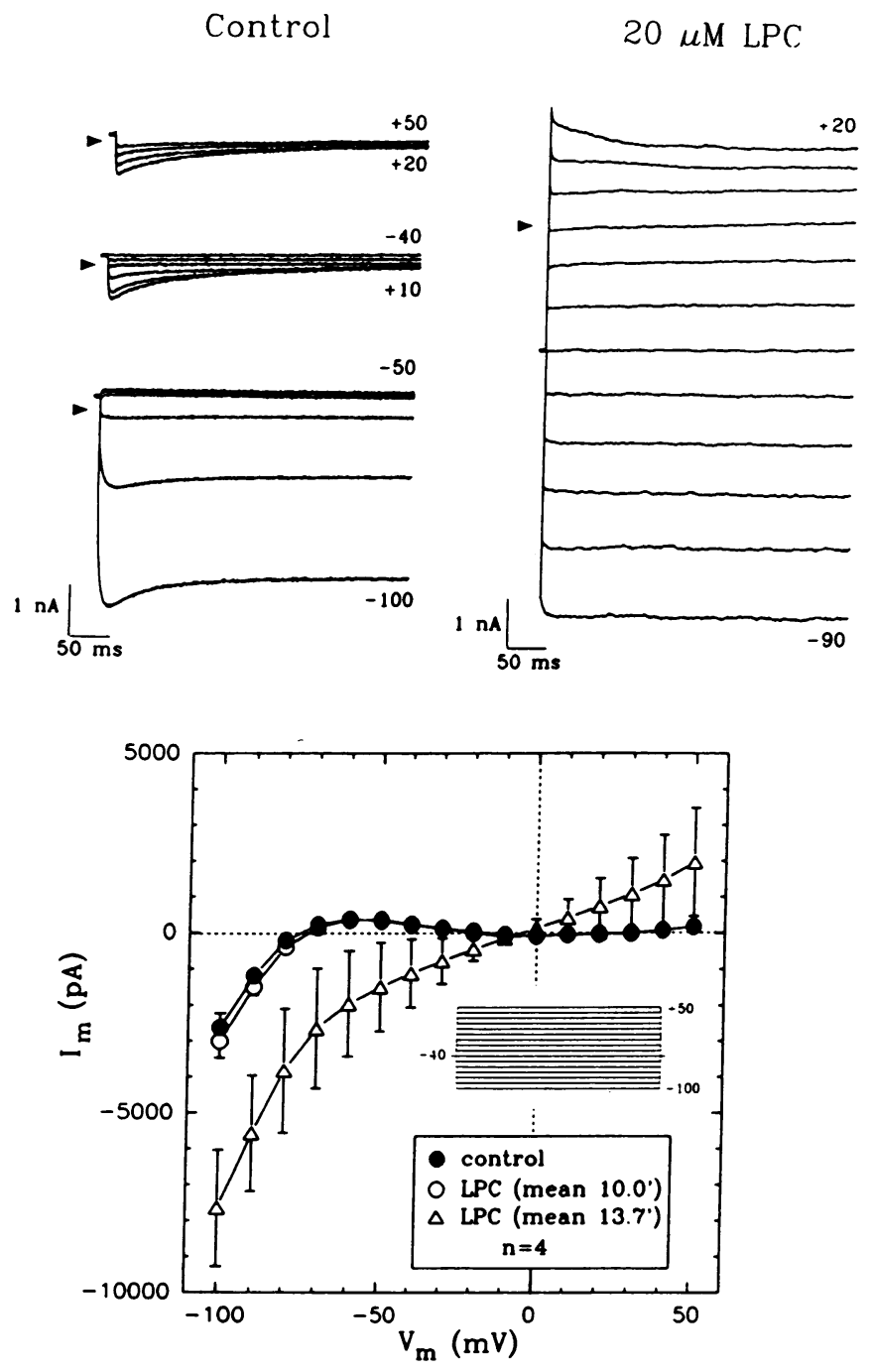

Figure 4. Effects of $20 \mu \mathrm{M}$ LPC on membrane currents in patchclamped myocytes. Upper tracings: Whole-cell membrane currents from a representative myocyte before (left traces) and after (right traces) exposure to LPC, elicited by 400 -ms voltage clamp steps from a holding potential of $-40 \mathrm{mV}$ to test potentials ranging from -100 to $+50 \mathrm{mV}$. After the addition of LPC, a large time-independent current appeared, obscuring all other currents. Note that the $\mathrm{Ca}^{2+}$ current was no longer apparent after LPC. Lower graph: I-V relationship (at $400 \mathrm{~ms}$ ) before and after the addition of $20 \mu \mathrm{M} \mathrm{LPC}$ in a total of four cells. The patch electrode solution was highly $\mathrm{Ca}^{2+}$-buffered with 14 mM EGTA. Room temperature.

or a $\mathrm{Cl}^{-}$current, since equimolar $\mathrm{Cl}^{-}$concentrations were present in the bath and patch electrode. To determine whether LPC-induced current was $\mathrm{Cl}^{-}$selective, experiments were conducted in five myocytes using an internal solution in which internal $\left[\mathrm{Cl}^{-}\right]$was reduced to $14 \mathrm{mM}$ by replacement with glutamate to yield an estimated $E_{\mathrm{Cl}}$ of $-60 \mathrm{mV}$. Under these conditions the LPC-induced current still reversed near $0 \mathrm{mV}$ (Fig. 7), inconsistent with a $\mathrm{Cl}^{-}$-selective current.

The above experiments were performed with $14 \mathrm{mM}$ EGTA in the patch electrode solution dialyzing the cytosol of the myocyte, making it unlikely that LPC-induced increases in $\left[\mathrm{Ca}^{2+}\right]_{\mathrm{i}}$ were responsible for the changes in the $I-V$ relations described above. Nevertheless, since LPC elevated $\left[\mathrm{Ca}^{2+}\right]_{i}$ in 

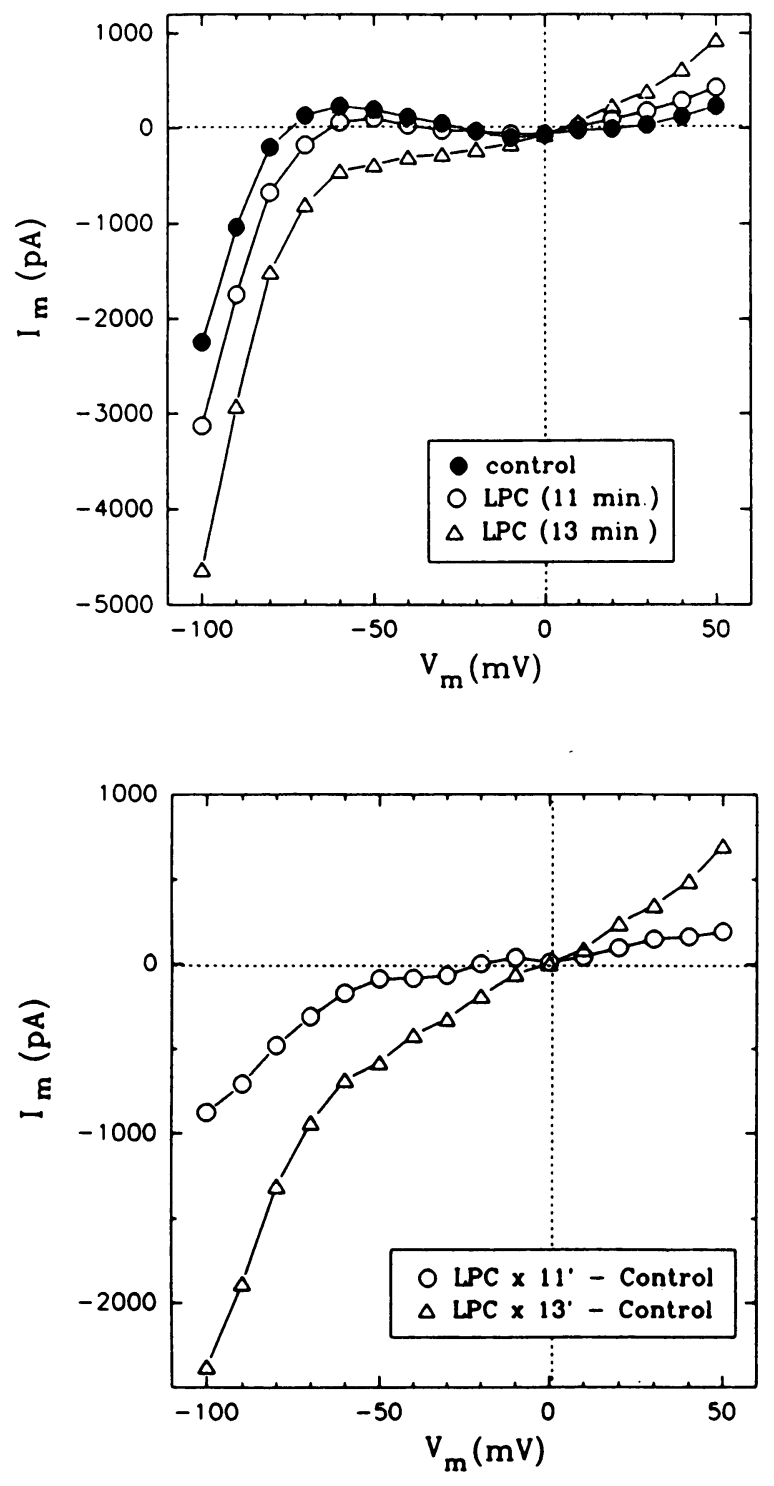

Figure 5. I-V relations (at $300 \mathrm{~ms}$ ) from a single cell under control conditions and at 11 and $13 \mathrm{~min}$ after the addition of $20 \mu \mathrm{M} \mathrm{LPC}$, illustrating the evolution of the depolarizing current. Same voltage clamp protocol as in Fig. 4. Lower graph shows the difference current obtained by subtracting the control $I-V$ curve from the curves at respectively 11 and $13 \mathrm{~min}$ after LPC. Note that the difference current reverses near $0 \mathrm{mV}$ in both cases. Room temperature.

the Indo-1-AM-loaded myocytes, which could activate inward depolarizing currents through nonselective cation channels (31) or electrogenic $\mathrm{Na}^{+}-\mathrm{Ca}^{2+}$ exchange (32), we performed further experiments to rule out the possibility that the observed changes in the $I-V$ relations were secondary to elevated $\left[\mathrm{Ca}^{2+}\right]_{\mathrm{i}}$. Fig. 8 shows membrane current traces from a myocyte subjected to a series of voltage clamps before (upper left panel) and during (upper middle panel) exposure to modified $\mathrm{Ca}^{2+}$-free bath solution containing $0.1 \mathrm{mM} \mathrm{CdCl}$ to block the $\mathrm{Ca}^{2+}$ current and $20 \mathrm{mM}$ caffeine to deplete sarcoplasmic reticulum $\mathrm{Ca}^{2+}$ stores. While in the presence of the modified perfusate, the myocyte was then exposed to $20 \mu \mathrm{M}$ LPC (upper right panel). The $I-V$ relations illustrated below (open symbols) show that LPC caused the same large current with a reversal poten- tial near $0 \mathrm{mV}$. The results in a total of four myocytes subjected to a similar protocol were similar (solid symbols). Thus it is highly unlikely that the depolarizing current induced by LPC was primarily activated by increases in free cytosolic $\left[\mathrm{Ca}^{2+}\right]$.

Effects of LPC on cardiac $\mathrm{K}^{+}$and $\mathrm{Ca}^{2+}$ currents. Although the LPC-induced changes in membrane potential could be adequately explained by the development of a nonselective depolarizing current, it is possible that other membrane currents which influence resting membrane potential and action poten-
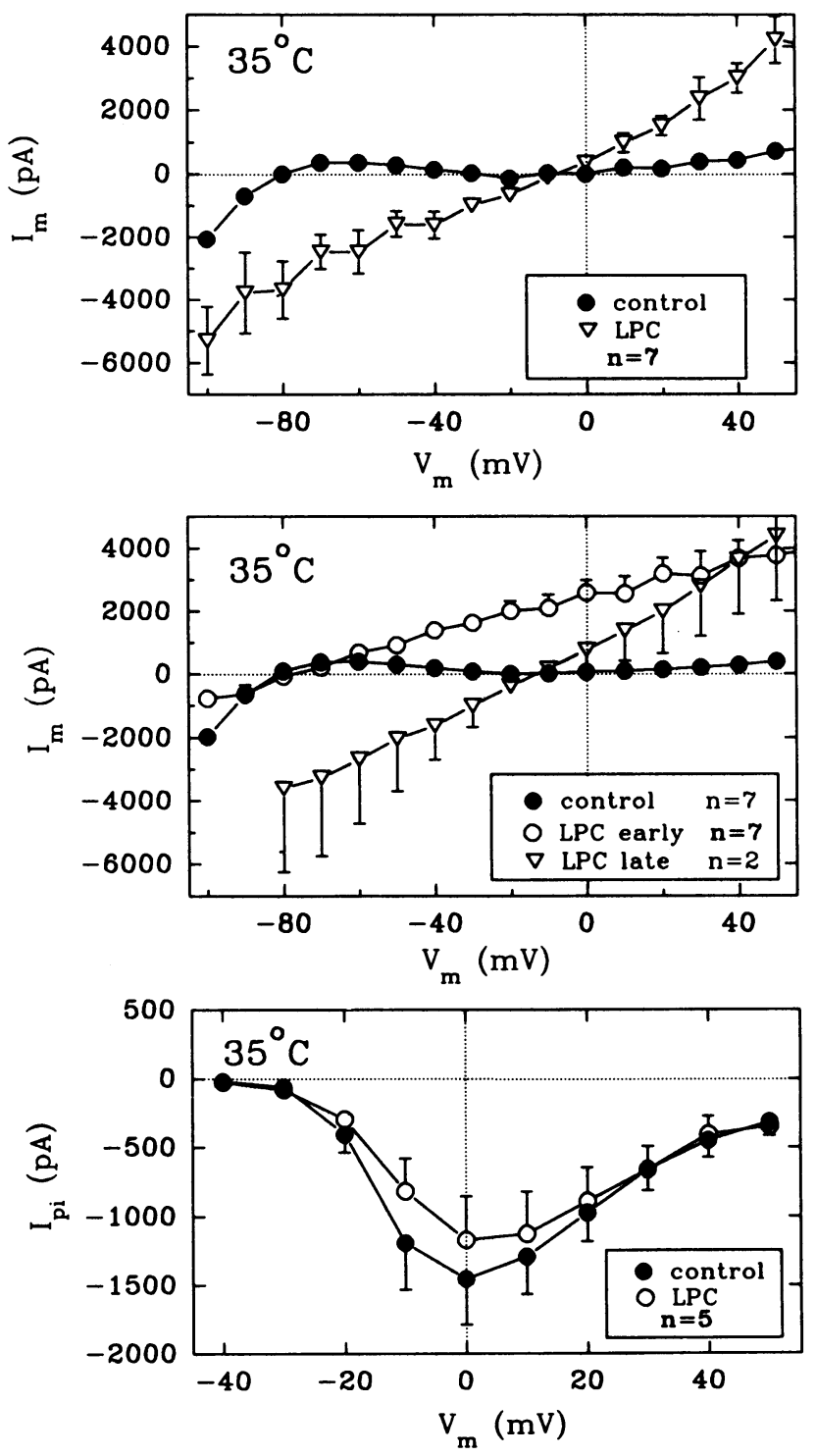

Figure 6. Effects of $20 \mu \mathrm{M} \mathrm{LPC}$ on the $I-V$ relationship in five patchclamped myocytes at $35^{\circ} \mathrm{C}$. Same protocol as in Fig. 4. Upper graph shows the $I-V$ relationship at $400 \mathrm{~ms}$ in seven myocytes under control conditions $(\bullet)$ and after exposure to LPC $(\Delta)$. Middle graph shows the $I-V$ relationship in seven other myocytes that developed a time-independent $\mathrm{K}^{+}$current during exposure to LPC (o). In two of these myocytes in which a series of voltage clamps was performed subsequently, the nonselective leak current had replaced the $\mathrm{K}^{+}$ current $(\Delta)$. Lower graph shows the $I-V$ relationship of the peak inward current under control conditions $(\bullet)$ and immediately before abrupt membrane depolarization during exposure to LPC (0) in five myocytes. 


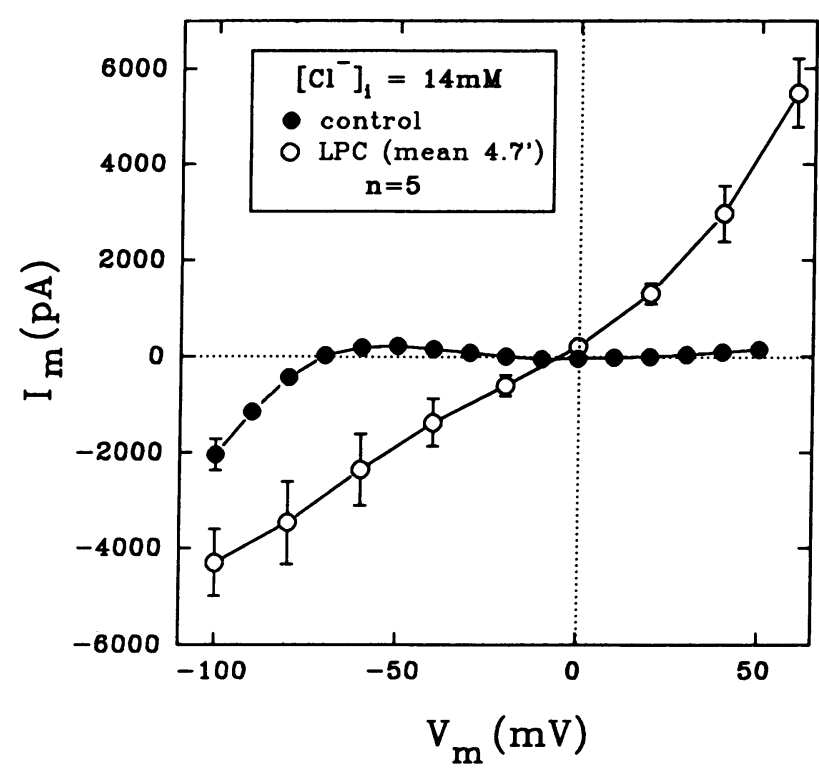

Figure 7. Effects of $20 \mu \mathrm{M} \mathrm{LPC}$ on the $I-V$ relationship at $400 \mathrm{~ms}$ in five patch-clamped myocytes with $[\mathrm{Cl}]_{\mathrm{i}}=14 \mathrm{mM}$. Same protocol as in Fig. 4. Room temperature.

tial configuration were also altered by LPC. Unfortunately, the nonselective current, once activated to a major degree, obscured the other membrane currents. However, we were able to assess the effects of LPC on specific membrane currents up until this point.
The inward rectifier $\mathrm{K}^{+}$current $\left(I_{\mathrm{K} 1}\right)$, the major determinant of resting membrane potential in heart muscle, has previously been reported to be depressed by $\operatorname{LPC}(14,19,20)$. Fig. 9 summarizes the effects of the $20 \mu \mathrm{M}$ LPC on $I_{\mathrm{K} 1}$ up until the time that the large nonselective current was activated (after a mean of $7.8 \mathrm{~min}$ ) in a total of 14 myocytes. $I_{\mathrm{K} 1}$ was elicited with 100 -ms voltage clamps to potentials ranging from -120 to -50 $\mathrm{mV}$ from a holding potential of $-40 \mathrm{mV}$. During superfusion with LPC, there was no significant change in the reversal potential. At potentials negative to $-80 \mathrm{mV}$, the magnitude of $I_{\mathrm{K} 1}$ appeared to increase although the difference was not statistically significant.

The delayed rectifier $\mathrm{K}^{+}$current $\left(I_{\mathrm{K}}\right)$ is a major determinant of action potential duration in ventricular muscle. Fig. 10 summarizes the effects of the $20 \mu \mathrm{M}$ LPC on $I_{\mathrm{K}}$ before activation of the large nonselective current (after a mean of $14 \mathrm{~min}$ ) in a total of three myocytes. In these experiments activation of $I_{\mathrm{K}}$ was estimated from the increase in outward current between 525 and $1,000 \mathrm{~ms}$ during a 1,000-ms voltage clamp pulse from a holding potential of $-40 \mathrm{mV}$ to test potentials between -30 and $+50 \mathrm{mV}$. Although the $\mathrm{Ca}^{2+}$ current was not specifically blocked, time-dependent changes in the $\mathrm{Ca}^{2+}$ current had ceased by $525 \mathrm{~ms}$ (e.g., see Fig. 11). The outward current shift from 525 to $1,000 \mathrm{~ms}$ was therefore attributable primarily to activation of $I_{\mathrm{K}}$, which had not yet reached steady-state activation by $1,000 \mathrm{~ms}$. $I_{\mathrm{K}}$ activated at potentials $>-30 \mathrm{mV}$, increasing to a mean value of $83 \pm 25 \mathrm{pA}$ after $1,000 \mathrm{~ms}$ at $+50 \mathrm{mV}$. LPC did not alter the magnitude (at $1,000 \mathrm{~ms}$ ) or time course (not shown) of activation of $I_{\mathrm{K}}$ before the development of the nonselective current.

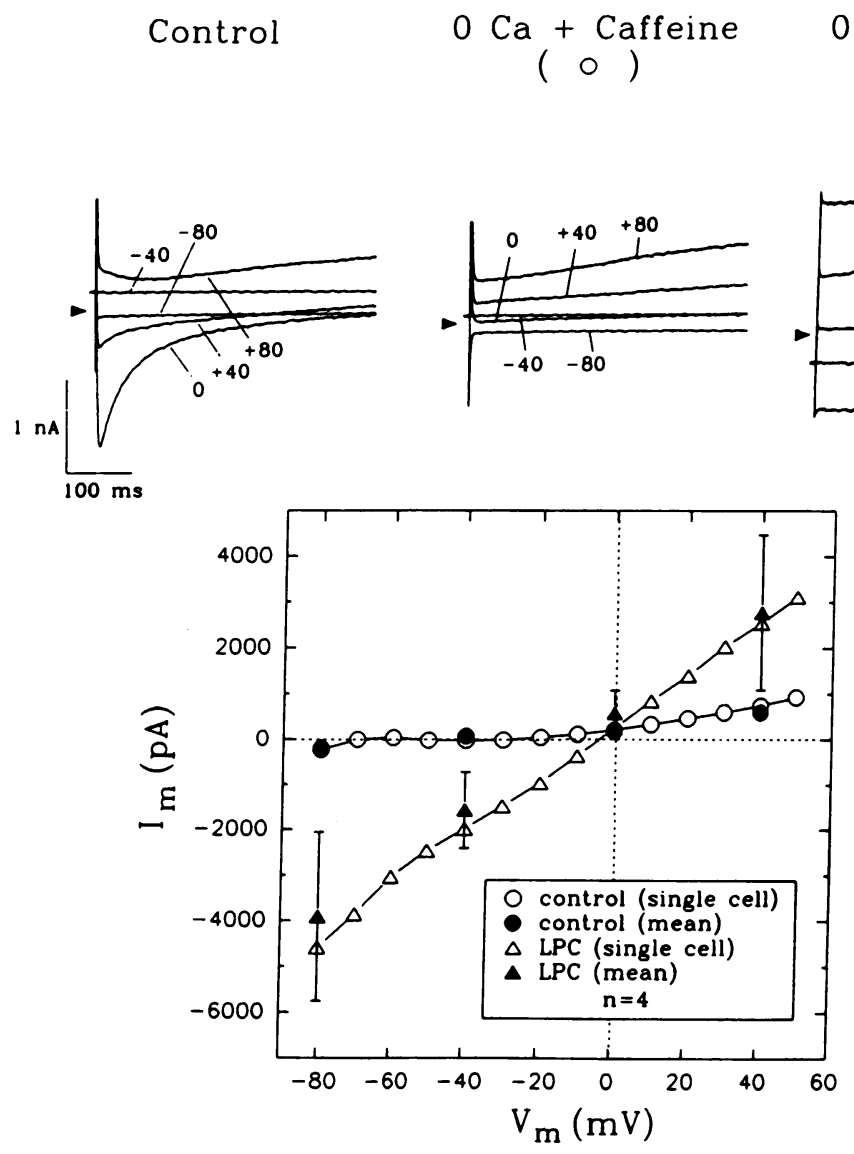

$0 \mathrm{Ca}+$ Caffeine $+20 \mu \mathrm{M} \mathrm{LPC}$

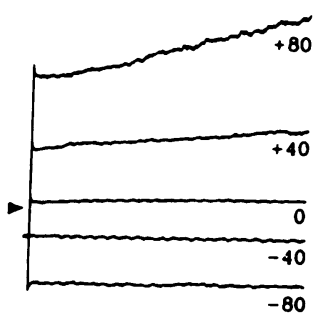

Figure 8. Effects of $20 \mu \mathrm{M} \mathrm{LPC}$ on membrane currents in patch-clamped myocytes superfused with a nominally $\mathrm{Ca}^{2+}$-free extracellular solution containing $20 \mathrm{mM}$ caffeine and 0.1 $\mathrm{mM} \mathrm{Cd}^{2+}$ and dialyzed intracellularly with 14 mM EGTA to eliminate potential sources of $\left[\mathrm{Ca}^{2+}\right]_{\mathbf{i}}$ overload. Upper tracings: Whole-cell currents elicited by $400-\mathrm{ms}$ voltage clamp pulses from a holding potential of $-40 \mathrm{mV}$ to test potentials from -80 to $+80 \mathrm{mV}$ (in $20-\mathrm{mV}$ steps) during superfusion with standard extracellular solution (left superimposed traces) and during superfusion with $\mathrm{Ca}^{2+}$-free solution containing caffeine and $\mathrm{Cd}^{2+}$ before (middle traces) and after (right traces) LPC in a representative myocyte. Lower graph: The 400-ms $I-V$ relationship in $\mathrm{Ca}^{2+}$-free extracellular solution containing caffeine and $\mathrm{Cd}^{2+}$ before (O) and after $(\triangle)$ LPC for the myocyte above. ( $\bullet$ $\Delta$ ) Mean \pm 1 SEM values in a total of four myocytes subjected to the same protocol. Room temperature. 


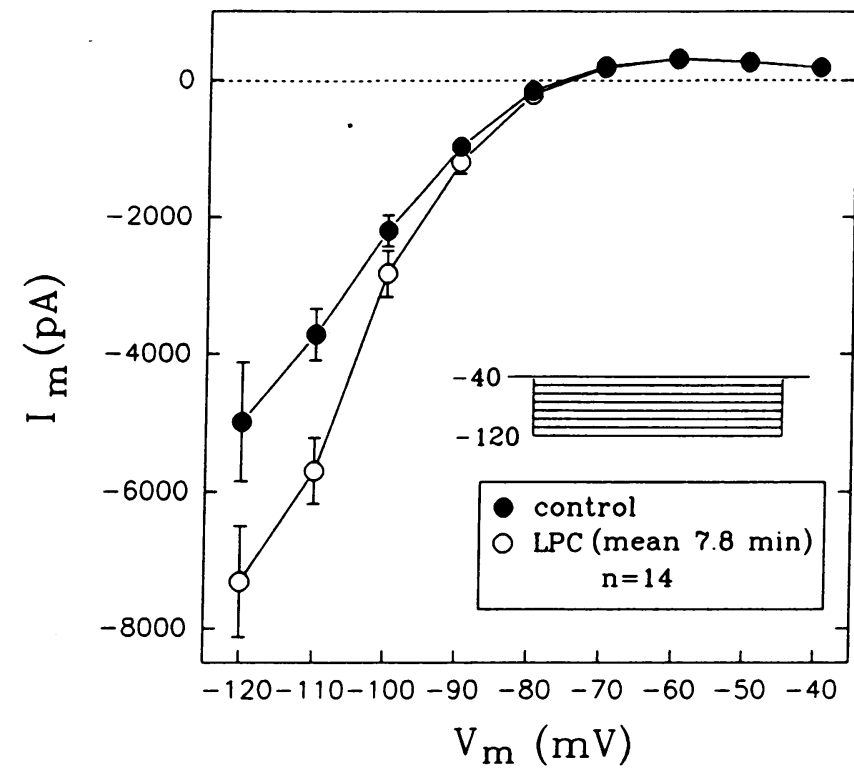

Figure 9. Effect of $20 \mu \mathrm{M} \mathrm{LPC}$ on $I_{\mathrm{K} 1}$. Graph shows the 100 -ms $I-V$ relation in a total of 14 cells. $I_{\mathrm{K} 1}$ was elicited by a $100-\mathrm{ms}$ voltage clamp pulses from a holding potential of $-40 \mathrm{mV}$ to test potentials between -120 and $-50 \mathrm{mV}$ before ( $(\bullet)$ and during (o) exposure to LPC for a mean of 7.8 min before the large depolarizing current developed and obscured reliable measurement of $I_{\mathrm{K} 1}$. Room temperature.

The L-type $\mathrm{Ca}^{2+}$ current $\left(I_{\mathrm{Ca}, \mathrm{L}}\right)$ is also an important determinant of action potential duration, and the T-type $\mathrm{Ca}^{2+}$ current $\left(I_{\mathrm{Ca}, \mathrm{T}}\right)$ may contribute to diastolic depolarization and automaticity (33). To examine the effects of LPC on $I_{\mathrm{Ca}, \mathrm{L}}$ and $I_{\mathrm{Ca}, \mathrm{T}}, \mathrm{Na}^{+}$ and $\mathrm{K}^{+}$currents were blocked by replacing $\mathrm{K}^{+}$and $\mathrm{Na}^{+}$with $\mathrm{Cs}^{+}$in both the internal and bath solutions and by adding $1 \mu \mathrm{M}$ TTX to the bath. $I_{\mathrm{Ca}, \mathrm{L}}$ and $I_{\mathrm{Ca}, \mathrm{T}}$ were separated by alternating the holding potential between -100 and $-40 \mathrm{mV}$ preceding voltage clamp pulses to test potentials ranging from -70 to +50 $\mathrm{mV}$, as described previously (34-36). As shown in Fig. 11, the voltage dependence of $I_{\mathrm{Ca}, \mathrm{L}}$ and $I_{\mathrm{Ca}, \mathrm{T}}$ was not significantly altered before the development of the nonselective current during exposure to $20 \mu \mathrm{M}$ LPC in the five cells studied. The modest decline in the amplitude of $I_{\mathrm{Ca}, \mathrm{L}}$ was indistinguishable from rundown of the current observed in the absence of LPC, and the amplitude of $I_{\mathrm{Ca}, \mathrm{T}}$ remained unchanged. In myocytes studied at $35^{\circ} \mathrm{C}, \mathrm{Ca}^{2+}$ currents were not isolated using $\mathrm{Cs}^{+}$and TTX, but the L-type $\mathrm{Ca}^{2+}$ current elicited by depolarizations from a holding potential of $-40 \mathrm{mV}$ appeared to be only modestly depressed just before the development of the LPC-induced inward current (Fig. 6, lower graph).

Effects of $L P C$ on processes regulating $\left[\mathrm{Ca}^{2+}\right]_{i}$ and excitation-contraction coupling. Although the nonselective depolarizing current induced by LPC could plausibly account for cytosolic $\mathrm{Ca}^{2+}$ overload observed in the Indo-1-AM-loaded myocytes, it is also possible that LPC also directly impaired processes regulating cytosolic $\left[\mathrm{Ca}^{2+}\right]$ and excitation-contraction coupling. To evaluate this possibility, the effects of LPC on cytosolic $\left[\mathrm{Ca}^{2+}\right]$ were studied in patch-clamped myocytes loaded with $0.1 \mathrm{mM}$ Fura-2 via the patch electrode (Fig. 12). Myocytes were held at $-40 \mathrm{mV}$ and depolarized every $30 \mathrm{~s}$ to a test potential of $0 \mathrm{mV}$ for $300 \mathrm{~ms}$, followed by repolarization to $-80 \mathrm{mV}$ for $340 \mathrm{~ms}$. At 2-min intervals the myocyte (with membrane potential held at $-40 \mathrm{mV}$ ) was exposed to a $650-\mathrm{ms}$ pulse of $5 \mathrm{mM}$ caffeine applied extracellularly with a rapid perfusion device to induce $\mathrm{Ca}^{2+}$ release from the sarcoplasmic reticulum (37). Membrane current, $\left[\mathrm{Ca}^{2+}\right]_{i}$ and cell shortening were monitored during the $\left[\mathrm{Ca}^{2+}\right]_{\mathrm{i}}$ transients elicited by both membrane depolarization and caffeine exposure. Fig. $12 A$ illustrates a typical $\left[\mathrm{Ca}^{2+}\right]_{\mathrm{i}}$ transient induced by a voltage clamp step to $0 \mathrm{mV}$ under control conditions. After exposure to 20 $\mu \mathrm{M}$ LPC for $5.5 \mathrm{~min}$ (Fig. $12 \mathrm{~B}$ ), a small inward shift in the holding current consistent with activation of a nonselective current had occurred, the $\mathrm{Ca}^{2+}$ current had run down significantly and the $\left[\mathrm{Ca}^{2+}\right]_{\mathrm{i}}$ transient was commensurately reduced. Diastolic $\left[\mathrm{Ca}^{2+}\right]_{\mathrm{i}}$, however, remained unchanged at $180 \mathrm{nM}$, indicating that any increased $\mathrm{Ca}^{2+}$ influx was still effectively buffered by the $\mathrm{Ca}^{2+}$-regulatory processes of the myocyte at this point. However, $1 \mathrm{~min}$ later, the nonselective current had increased markedly (Fig. $12 \mathrm{C}$ ) and diastolic $\left[\mathrm{Ca}^{2+}\right]_{\mathrm{i}}$ at the holding potential of $-40 \mathrm{mV}$ increased to $250 \mathrm{nM}$, consistent with the inability of the myocyte to buffer the increased $\mathrm{Ca}^{2+}$ influx.
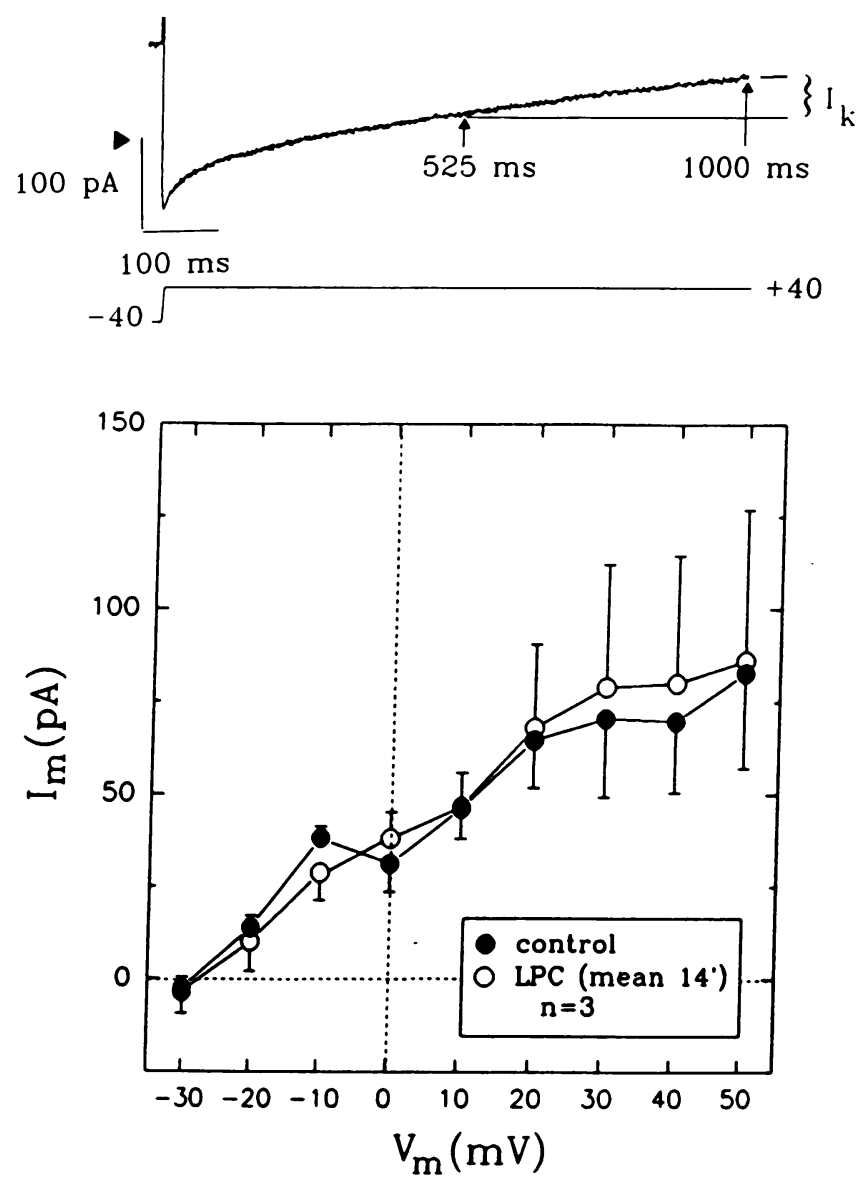

Figure 10. Effect of $20 \mu \mathrm{M} \mathrm{LPC}$ on the $I_{\mathrm{K}}$. Upper trace illustrates the method of estimating $I_{\mathrm{K}}$, which was taken as the difference between the current at 1,000 ms (the end of the test clamp) and $525 \mathrm{~ms}$ (after time-dependent changes in $I_{\mathrm{Ca}}$ were completed) during 1-s voltage clamp pulses from a holding potential of $-40 \mathrm{mV}$ to test potentials from -30 to $+50 \mathrm{mV}$. Lower graph shows the $I-V$ curve for $I_{\mathrm{K}}$ before $(\bullet)$ and during (O) exposure to LPC for a mean of $14 \mathrm{~min}$ before the large depolarizing current developed and obscured reliable measurement of $I_{\mathrm{K}}$. Room temperature. 


\section{Control}
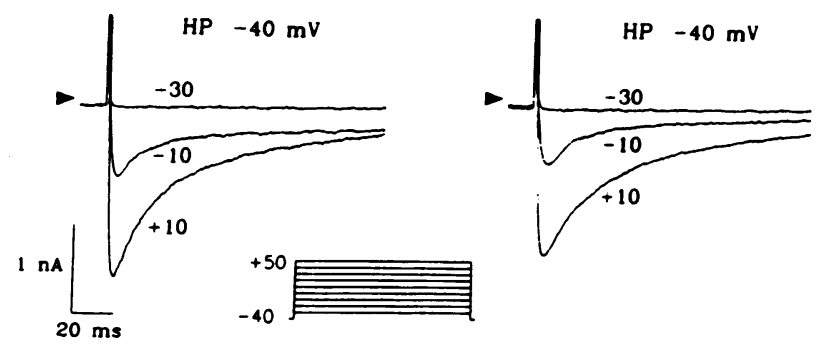
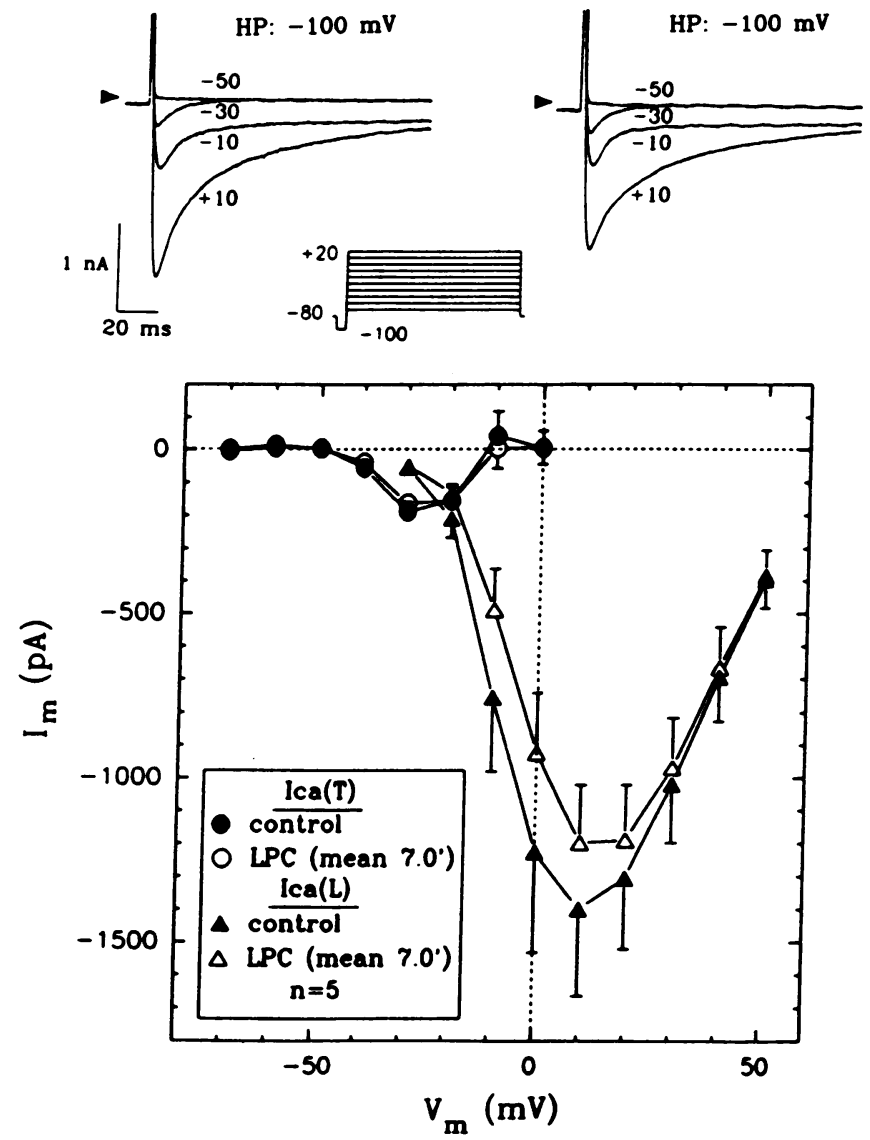

Figure 11. Effect of $20 \mu \mathrm{M} \mathrm{LPC}$ on the $I_{\mathrm{C}, \mathrm{T}}$ and $I_{\mathrm{Ca}, \mathrm{L}}$. Upper traces illustrate voltage clamp pulses from a holding potential of either -100 or $-40 \mathrm{mV}$ to the various test potentials indicated. $I_{\mathrm{C}_{2} \mathrm{~L}}$ was measured as the current during the clamps from the holding potential of $-\mathbf{4 0}$ $\mathrm{mV}$ (where $I_{\mathrm{C}, \mathrm{T}}$ is inactivated), whereas $I_{\mathrm{Ca}, \mathrm{T}}$ was obtained as the difference current between clamps from two different holding potentials (34-36). Right and left traces are before and after LPC in a representative myocyte. Lower graph shows the peak $I-V$ relation for $I_{\mathrm{C}, \mathrm{T}}$ (circles) and $I_{\mathrm{Ca}, \mathrm{L}}$ (triangles) in five cells before (solid symbols) and during (open symbols) exposure to LPC for a mean of $7 \mathrm{~min}$ before the large depolarizing current developed and obscured reliable measurement of $I_{\mathrm{Ca}}$. Room temperature.

The $\mathrm{Ca}^{2+}$ current and the magnitude of the $\left[\mathrm{Ca}^{2+}\right]_{\mathrm{i}}$ transient were further reduced. Upon repolarization to $-80 \mathrm{mV}$, diastolic $\left[\mathrm{Ca}^{2+}\right]_{\mathrm{i}}$ returned to the control level of $180 \mathrm{nM}$, probably due to the enhancement of $\mathrm{Ca}^{2+}$ efflux via electrogenic $\mathrm{Na}^{+}$$\mathrm{Ca}^{2+}$ exchange, which is electrochemically more favorable at a

membrane potential of $-80 \mathrm{mV}$ than at $-40 \mathrm{mV}$ (38). The effects of LPC on the caffeine-induced $\left[\mathrm{Ca}^{2+}\right]_{i}$ transient in this myocyte are shown in Fig. 12, $D$ and $E$. Under control conditions (Fig. $12 \mathrm{D}$ ), the $\left[\mathrm{Ca}^{2+}\right]_{\mathrm{i}}$ transient was accompanied by a small transient inward dip in the holding current which has been attributed to electrogenic $\mathrm{Na}^{+}-\mathrm{Ca}^{2+}$ exchange (37). After exposure to LPC for 5.75 min (Fig. $12 E$, just after the voltage clamp pulse in Fig. $12 \mathrm{~B}$ ), when a modest increase in the holding current at $-40 \mathrm{mV}$ had developed, the caffeine-induced $\left[\mathrm{Ca}^{2+}\right]_{\mathrm{i}}$ transient was slightly greater in magnitude and reuptake of $\left[\mathrm{Ca}^{2+}\right]_{\mathrm{i}}$ was modestly delayed after washout of caffeine. The $\mathrm{Na}^{+}-\mathrm{Ca}^{2+}$ exchange current remained intact and was slightly increased in magnitude consistent with the larger $\left[\mathrm{Ca}^{2+}\right]_{\mathrm{i}}$ transient. After the nonselective current increased further (Fig. 12 $C)$, the cell rapidly went into a severe irreversible contracture before another caffeine pulse could be delivered. Similar results were obtained in four additional myocytes.

These findings suggest that the development of the nonselective current began before there was a significant increase in diastolic $\left[\mathrm{Ca}^{2+}\right]_{\mathrm{i}}$. Furthermore, gating of $\mathrm{Ca}^{2+}$ release from the sarcoplasmic reticulum by the $\mathrm{Ca}^{2+}$ current remained qualitatively normal, and reuptake of $\left[\mathrm{Ca}^{2+}\right]_{i}$ was not greatly impaired before marked activation of the nonselective current. Sarcoplasmic reticulum $\mathrm{Ca}^{2+}$ stores remained full and the ability of the sarcoplasmic reticulum to both sequester and release $\mathrm{Ca}^{2+}$ remained intact. Finally $\mathrm{Na}^{+}-\mathrm{Ca}^{2+}$ exchange also grossly appeared to function appropriately.

Fig. 13 illustrates more clearly the relationship between diastolic $\left[\mathrm{Ca}^{2+}\right]_{\mathrm{i}}$ and the nonselective current induced by LPC in another myocyte. Under control conditions (left traces), the caffeine-induced $\left[\mathrm{Ca}^{2+}\right]_{\mathrm{i}}$ transient was accompanied by a small inward $\mathrm{Na}^{+}-\mathrm{Ca}^{2+}$ exchange current and a contraction, which was also monitored in this myocyte. After exposure to $20 \mu \mathrm{M}$ LPC for $9.5 \mathrm{~min}$, diastolic $\left[\mathrm{Ca}^{2+}\right]_{i}$ was unchanged although the holding current had become more inward, and the caffeine pulse was repeated. During the ensuing $\left[\mathrm{Ca}^{2+}\right]_{\mathrm{i}}$ transient, an abrupt step-like increase in holding current occurred (first arrow). The $\left[\mathrm{Ca}^{2+}\right]_{\mathrm{i}}$ transient was similar in magnitude but prolonged, accounting for the larger contraction. After washout of caffeine, $\left[\mathrm{Ca}^{2+}\right]_{\mathrm{i}}$ returned rapidly to the same diastolic level and the cell relaxed despite the activation of the nonselective current. At this point, however, a much larger stepwise increase in holding current suddenly occurred (second arrow) despite the normal level of diastolic $\left[\mathrm{Ca}^{2+}\right]_{i}$. Diastolic $\left[\mathrm{Ca}^{2+}\right]_{\mathrm{i}}$ increased rapidly after the onset of this current and the cell shortened irreversibly, indicating that the abrupt increase in the nonselective current in this myocyte was clearly the cause rather than the result of increased $\left[\mathrm{Ca}^{2+}\right]_{\mathrm{i}}$.

Effects of saponin on the action potential, membrane currents, and $\left[\mathrm{Ca}^{2+}\right]_{i}$ transients. Because the major effect of 20 $\mu \mathrm{M}$ LPC was to induce a nonselective leak current, consistent with a detergent effect, we investigated whether a nonspecific membrane detergent, saponin, had similar effects on cardiac function. Fig. 14 illustrates the effects of $0.005 \%$ saponin on $\left[\mathrm{Ca}^{2+}\right]_{\mathrm{i}}$ transients and contraction. In four field-stimulated indo-1-AM-loaded myocytes, saponin caused a variable transient-positive inotropic effect $(36.4 \pm 18.0 \%$ in two of four myocytes) followed by automaticity and progressive contracture leading to cell death in all four myocytes. The associated $\left[\mathrm{Ca}^{2+}\right]_{i}$ transients showed progressive increases in diastolic and systolic values of $F_{405} / F_{495}$, similar to LPC. In four myocytes monitored under whole-cell current clamp conditions, saponin in- 

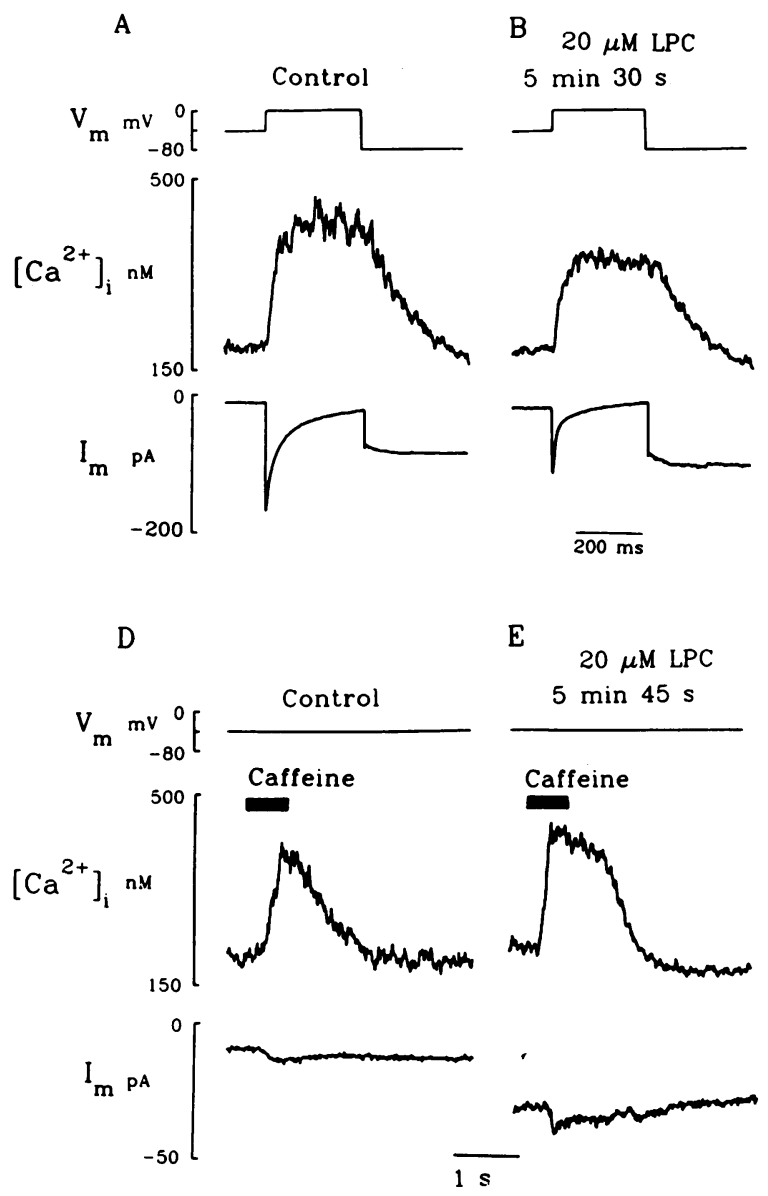

duced abrupt depolarization and spontaneous automaticity (Fig. 15). The $I-V$ curve averaged from seven cells showed the appearance of a large time-independent current reversing at near $0 \mathrm{mV}$, similar to the effect of LPC.

\section{Discussion}

Biological effects of lysophospholipids. Lysophospholipids are amphiphilic molecules formed from the breakdown of membrane phospholipids by phospholipase $\mathrm{A}_{2}$. Unlike other phospholipids, lysophospholipids do not spontaneously form bilayers and are more soluble. By inserting into the membrane as free monomers and altering the lipid environment, lysophosphoglycerides may have specific effects on integral membrane proteins such as ion channels or transporters. At higher concentrations, lysophosphoglycerides are more likely to form micelles, causing nonselective membrane leakiness and eventually disrupting biological membranes via a nonspecific detergent action $(11,39)$. Which of these effects predominates, however, depends critically on concentration, temperature, and other experimental factors. Previous studies in cardiac muscle have found that LPC concentrations of 10-75 $\mu \mathrm{M}$ are sufficient to produce electrophysiological derangements in multicellular (13-18) and isolated myocyte preparations (19, 20) studied at room temperature or $37^{\circ} \mathrm{C}$. These concentrations are comparable to the reported critical micelle concentration, which may range from 7 to $80 \mu \mathrm{M}(40,41)$. In this study, in which the detergent effects of LPC appeared to predominate, the effects of LPC on membrane potential and currents at
$20 \mu \mathrm{M} \mathrm{LPC}$ $6 \min 30 \mathrm{~s}$
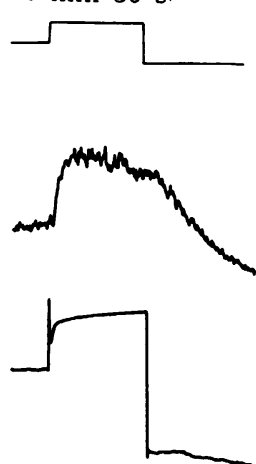

Figure 12. Effects of $20 \mu \mathrm{M} \mathrm{LPC}$ on $\left[\mathrm{Ca}^{2+}\right]_{i}$ and membrane currents in a patch clamped myocyte loaded with $0.1 \mathrm{mM}$ Fura-2 via the patch electrode. Panels $A-C$ illustrate the $\left[\mathrm{Ca}^{2+}\right]_{\mathrm{i}}$ transient and membrane current during 300 -ms voltage clamp pulses to $0 \mathrm{mV}$ from a holding potential of $-40 \mathrm{mV}$, followed by repolarization to $-80 \mathrm{mV}$ under control conditions $(A)$ and after $5.5(B)$ and $6.5(C)$ min of exposure to LPC. Panels $D$ and $E$ show the $\left[\mathrm{Ca}^{2+}\right]_{\mathrm{i}}$ transient and membrane current elicited by 650 -ms exposure to $5 \mathrm{mM}$ caffeine (indicated by solid bars) under control conditions $(D)$ and after exposure to LPC for $7.75 \mathrm{~min}(E)$. Membrane potential was held constant at -40 $\mathrm{mV}$. Room temperature. See text for further details.

room temperature were qualitatively similar for 5,20 , and 40 $\mu \mathrm{M}$, the only difference being a shorter average time to onset of depolarization with increasing concentrations. This is consistent with the idea that under our experimental conditions, cellular membranes progressively accumulated LPC until a critical threshold was reached at which the detergent effect induced the observed electrophysiological abnormalities. However, we cannot exclude the possibility that had lower LPC concentrations been investigated in detail, more specific effects of LPC might have been observed. It is also possible that the cell isolation procedure modulates the membrane properties of the myocytes in some manner that makes them more susceptible to the nonspecific detergent actions of LPC.

Temperature may also be an important factor influencing whether lysophosphoglycerides cause specific or nonspecific effects. For example, low temperature has been reported to potentiate the ability of LPC to lyse erythrocyte membrane (39) and to increase permeability of bilayer vesicles to large ions (42), probably because membranes are less "elastic" and are therefore unable to incorporate as much LPC before becoming leaky, or because LPC is distributed less homogeneously in the membrane. On the other hand, lower temperature may decrease the critical micellar concentration of LPC (43), and slow the kinetics of membrane lysis (39). The cytolytic effects of LPC and its temperature dependence are also likely to be highly species and organ dependent (39), possibly reflecting differing lipid compositions of the cell membranes. In the present study, however, we saw no major qualitative differences among effects of $20 \mu \mathrm{M}$ of LPC on membrane potential, mem- 


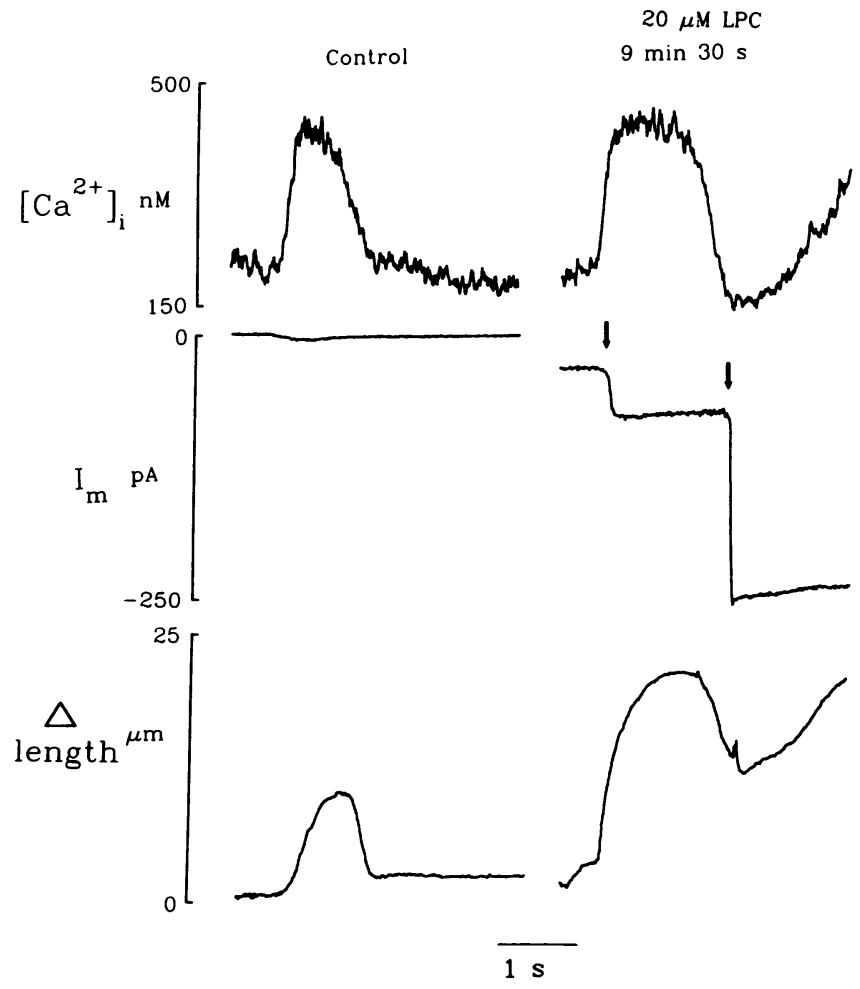

Figure 13. Effects of $20 \mu \mathrm{M} \mathrm{LPC}$ on the caffeine-induced $\left[\mathrm{Ca}^{2+}\right]_{\mathrm{i}}$ transient, membrane currents and cell shortening in another patch clamped myocyte loaded with $0.1 \mathrm{mM}$ Fura- 2 via the patch electrode. Room temperature. See text for details.

brane currents, or $\left[\mathrm{Ca}^{2+}\right]_{\mathrm{i}}$ transients at $35^{\circ} \mathrm{C}$ and at room temperature, although we did not study myocytes at $35^{\circ} \mathrm{C}$ as extensively. However, at $35^{\circ} \mathrm{C}$ the average time to onset of membrane depolarization was shorter and in $50 \%$ of myocytes LPC activated a $\mathrm{K}^{+}$current before activating the large nonselective current. We were unable to identify conclusively the nature of this $\mathrm{K}^{+}$current since it tended to be obscured by the progressive increase in the large nonselective current. However, we speculate from its characteristic time independence and lack of strong inward or outward rectification that it was the ATP-sensitive $\mathrm{K}^{+}$current. At $35^{\circ} \mathrm{C}$, myocytes may be less able to tolerate the metabolic stress of the initial LPC-induced leak current. It is unlikely that LPC directly activated ATP-sensitive $\mathrm{K}^{+}$ channels, since LPC has been shown to inhibit these channels in excised membrane patches (24). We cannot exclude the possibility that the $\mathrm{K}^{+}$current was due to another type of $\mathrm{K}^{+}$channel, such as arachidonic acid- or $\mathrm{Na}^{+}$-activated $\mathrm{K}^{+}$channels $(44,45)$.

$L P C$ and intracellular $\left[\mathrm{Ca}^{2+}\right]$. Consistent with previous findings showing that LPC increased ${ }^{45} \mathrm{Ca}^{2+}$ uptake in isolated myocytes $(21,22)$, we found that in externally paced unimpaled myocytes, LPC caused a progressive rise in free cytosolic $\left[\mathrm{Ca}^{2+}\right]$ which, after a transient positive inotropic effect, led to spontaneous beating, irreversible contracture and cell death. In patch-clamped myocytes, LPC activated a large inward current which depolarized the resting membrane potential and was associated with the development of automaticity and other arrhythmogenic electrophysiological abnormalities qualitatively similar to those reported previously in isolated myocytes (19, 20) and multicellular preparations (13-18). It has been sug- gested that elevated $\left[\mathrm{Ca}^{2+}\right]_{i}$ may be the primary cause of these electrophysiological abnormalities through activation of arrhythmogenic inward current through nonselective cation channels (31) or electrogenic $\mathrm{Na}^{+}-\mathrm{Ca}^{2+}$ exchange (32). However, our findings clearly demonstrate that, under our experimental conditions, at least initially the LPC-induced inward depolarizing current was not caused by elevated cytosolic $\left[\mathrm{Ca}^{2+}\right]_{\mathrm{i}}$, because $(a)$ it still developed under conditions in which elevated $\left[\mathrm{Ca}^{2+}\right]_{i}$ was prevented by removing extracellular $\left[\mathrm{Ca}^{2+}\right]$, depleting intracellular $\mathrm{Ca}^{2+}$ stores, and strongly buffering cytosolic $\left[\mathrm{Ca}^{2+}\right]$ with EGTA (Fig. 8), and $(b)$ in Fura-2 loaded patch-clamped myocytes diastolic $\left[\mathrm{Ca}^{2+}\right]_{i}$ remained
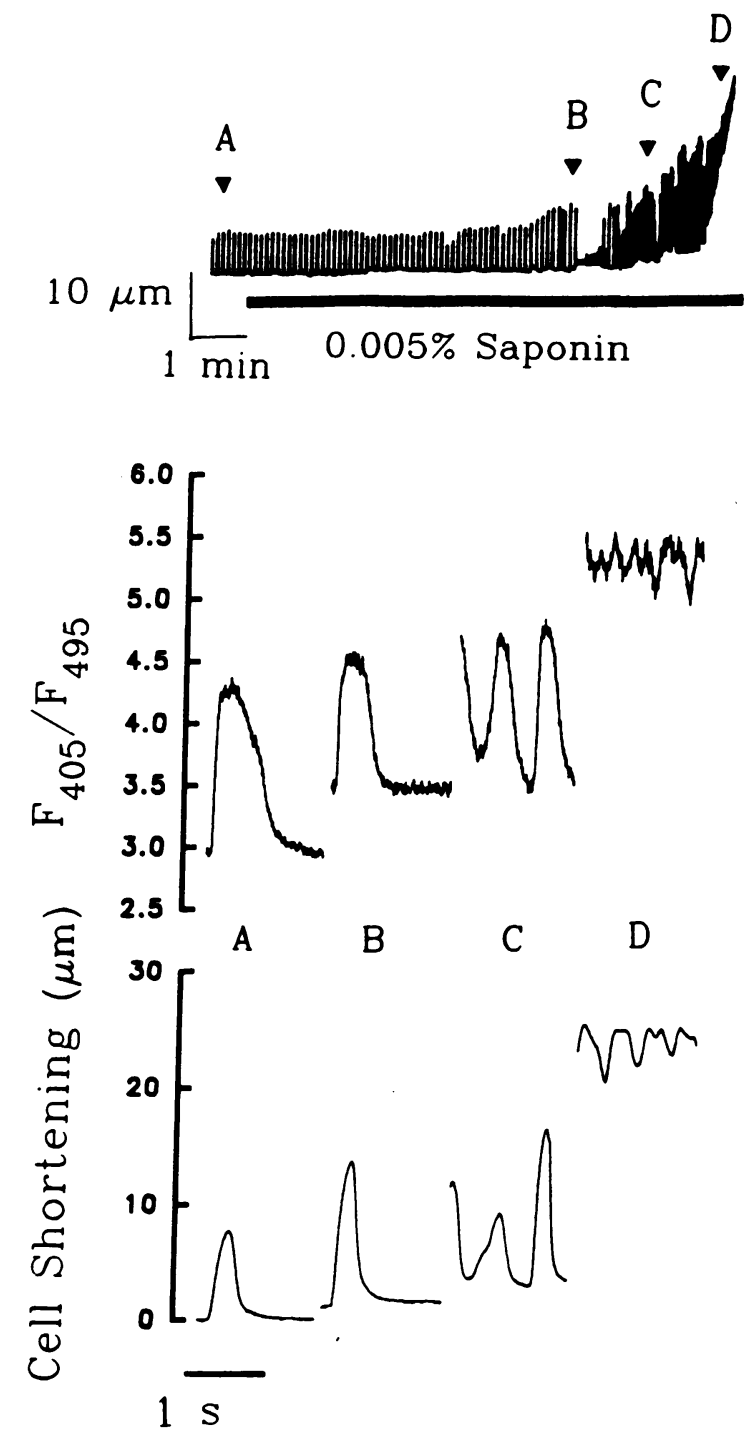

Figure 14. Effect of saponin $(0.005 \%)$ on $\left[\mathrm{Ca}^{2+}\right]_{\mathrm{i}}$ and cell shortening in an Indo-1-AM-loaded myocyte paced at $0.2 \mathrm{~Hz}$. Top tracing: Continuous recording of cell shortening during exposure to saponin, demonstrating transient positive inotropy $(B)$, spontaneous contractile activity, and progressive contracture ( $C$ and $D$ ) leading to cell death. Middle tracing: Measurements of the ratio $\left(F_{405} / F_{495}\right)$ of cell fluorescence at 405- and 495-nm wavelengths (excitation at $360 \mathrm{~nm}$ ) indicating qualitative changes in $\left[\mathrm{Ca}^{2+}\right]_{i}$ during paced beats at the representative points $A-D$ indicated above. Lower tracing: Cell shortening associated with the $\left[\mathrm{Ca}^{2+}\right]_{\mathrm{i}}$ transients at points $A-D$. Room temperature. 
control
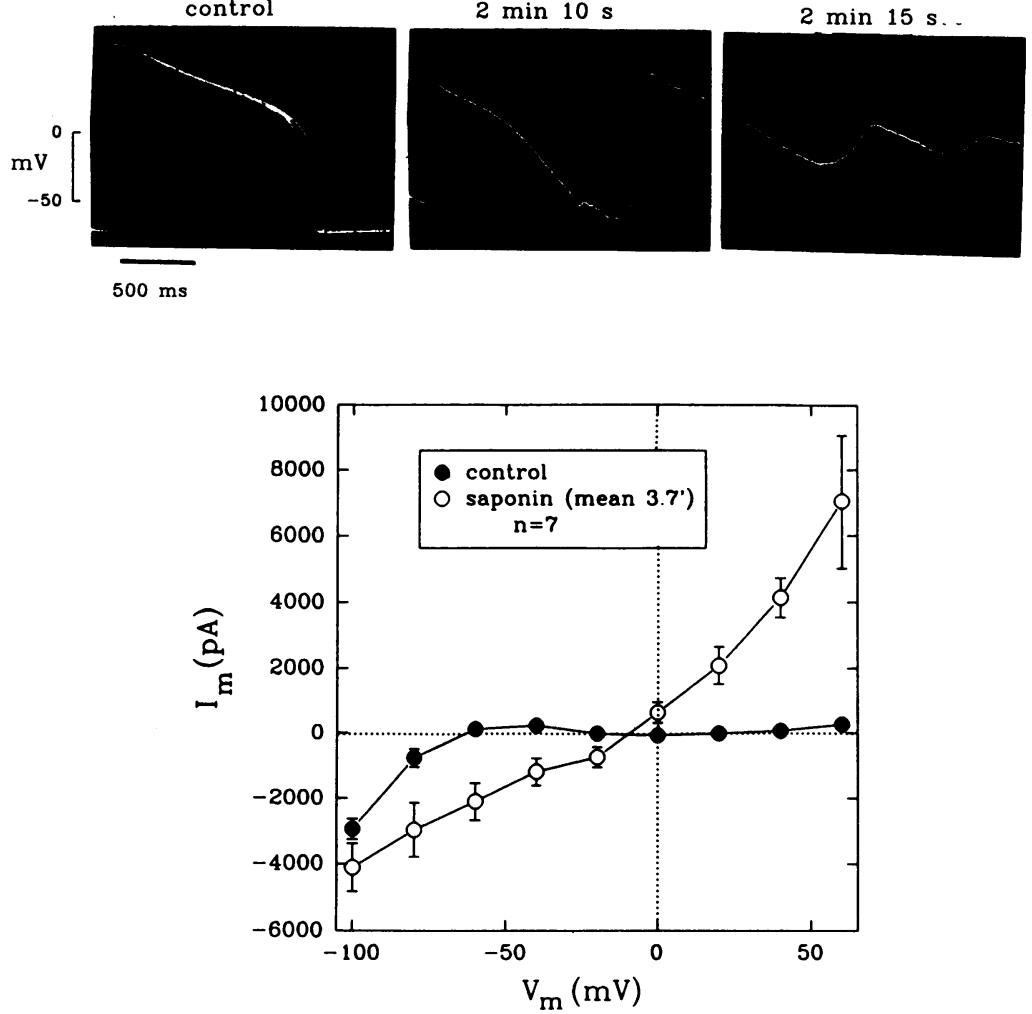

Figure 15. Effect of saponin on intracellular potential and membrane currents in patch-clamped myocytes. Upper panels show a representative myocyte stimulated at $0.2 \mathrm{~Hz}$ in the current clamp mode at $25^{\circ} \mathrm{C}$. After 2 min of exposure to saponin, the resting membrane potential depolarized modestly, action potential duration shortened, and spontaneous automaticity occurred (second panel). Shortly thereafter, the resting potential depolarized more completely, with oscillatory activity (third panel). Lower graph shows the $I-V$ relationship (at $400 \mathrm{~ms}$ ) before and after the addition of saponin in a total of seven cells at $25^{\circ} \mathrm{C}$. Same protocol as in Fig. 4. The patch electrode solution was highly $\mathrm{Ca}^{2+}$-buffered with 14 mM EGTA. normal during the early phases of activation of the depolarizing current, and did not increase until after the current became quite large (Fig. 13). In fact, up to the point at which the large depolarizing current developed, we found no evidence that LPC significantly impaired the major elements regulating excitation-contraction coupling and $\left[\mathrm{Ca}^{2+}\right]_{\mathrm{i}}$ homeostasis, with the possible exception of accelerated rundown of the $\mathrm{Ca}^{2+}$ current. Both release and sequestration of $\mathrm{Ca}^{2+}$ by the sarcoplasmic reticulum and $\mathrm{Na}^{+}-\mathrm{Ca}^{2+}$ exchange appeared grossly intact and capable of maintaining appropriate diastolic $\left[\mathrm{Ca}^{2+}\right]_{i}$ levels although the rate of $\left[\mathrm{Ca}^{2+}\right]_{i}$ reuptake was modestly depressed after a caffeine pulse (Figs. 12 and 13). However, it is possible that these processes deteriorated rapidly once the large depolarizing current developed, since in isolated organelles, LPC has been reported to inhibit both $\mathrm{Na}^{+}-\mathrm{Ca}^{2+}$ exchange activity (46) and $\mathrm{Ca}^{2+}$ uptake by the sarcoplasmic reticulum $(47,48)$. Also, we have not characterized the effects of LPC on a number of the known ionic currents and transport processes which could influence resting membrane potential and $\left[\mathrm{Ca}^{2+}\right]_{i}$. Examples include the $\mathrm{Na}^{+}$channel, whose inactivation kinetics have been shown to be altered by LPC (23), and $\mathrm{Na}^{+}-\mathrm{K}^{+}$ATPase and the ATP-sensitive $\mathrm{K}^{+}$channel, both of which are inhibited by LPC $(24,49)$. We cannot rule out the possibility that specific effects on these processes contributed to the effects of LPC on $\left[\mathrm{Ca}^{2+}\right]_{i}$ in the Indo-1-AM-loaded cells.

These observations suggest that the LPC-induced depolarizing current directly caused the increase in diastolic $\left[\mathrm{Ca}^{2+}\right]_{i}$ rather than vice versa. The depolarizing current was nonselective, since its reversal potential was near $0 \mathrm{mV}$. In this case, cytosolic $\left[\mathrm{Ca}^{2+}\right]_{i}$ overload could have resulted directly from $\mathrm{Ca}^{2+}$ permeation through the nonselective pathway, or been secondary to permeation of other ions such as $\mathrm{Na}^{+}$. Marked cytosolic $\mathrm{Na}^{+}$loading, for example, could secondarily increase
$\mathrm{Ca}^{2+}$ entry via reverse $\mathrm{Na}^{+}-\mathrm{Ca}^{2+}$ exchange. In view of the abruptness of the membrane depolarization after exposure to LPC and the physical characteristics of this amphiphile, we speculate that depolarization was caused by disruption of the membrane via the detergent action of LPC, making it "leaky" to most ions including $\mathrm{Ca}^{2+}$. This hypothesis is supported by the observation that the membrane detergent saponin had similar effects on membrane potential and currents, cell shortening, and $\left[\mathrm{Ca}^{2+}\right]_{i}$ transients. Since we identified no major changes in individual membrane currents or other processes, we have no evidence that the deleterious effects of LPC on cardiac function were mediated by modulation of specific lipid-integral membrane protein interactions under our experimental conditions.

Electrophysiological actions of LPC. The arrhythmogenic effects of LPC observed in our study are similar to those noted previously in isolated myocytes $(19,20)$ and in multicellular preparations (13-18). In the latter case, however, the onset of membrane depolarization, action potential changes, and automaticity were typically more gradual and sometimes partially reversible. Owing to the syncytial nature of multicellular preparations, a more gradual onset of the electrophysiological changes would be expected if there was significant temporal variation in the susceptibility of individual myocytes in the preparation to injury by LPC. The development of sufficient LPC-induced nonselective current to abruptly depolarize an isolated myocyte would, in a multicellular preparation, be offset by electrotonic hyperpolarizing current flow from adjacent unaffected myocytes, attenuating the magnitude of membrane depolarization in the affected myocyte. Eventually, as the affected myocyte became progressively $\left[\mathrm{Ca}^{2+}\right]_{\mathrm{i}}$ overloaded, the low electrical resistance connections with adjacent myocytes would stop functioning, and the myocyte would fully depolar- 
ize as it became electrically uncoupled from the remainder of the heart. Concomitantly its depolarizing effect on the membrane potential of the remaining myocytes would drop out. A significant temporal variation in the sensitivity of individual myocytes to LPC was observed in our study, and may be even greater in a superfused multicellular preparation, in which cells on the surface would be exposed to higher LPC concentrations than cells in the diffusion-limited core. An inhomogeneous response could explain several apparent discrepancies between our results and those obtained in multicellular cardiac preparations. Clarkson and Ten Eick (14), who studied the effects of LPC in superfused cat papillary muscles under voltage-clamp conditions, reported that LPC depressed the slow inward current and time-dependent and time-independent $\mathrm{K}^{+}$ currents, and postulated that LPC may act as a nonspecific depressant of all membrane currents. They also found that LPC caused an increase in membrane resistance near the resting potential, which they argued was evidence against an LPCinduced increase in nonspecific membrane leakiness. This is a valid argument if the effects of LPC occurred homogeneously and simultaneously in all the myocytes in their preparation. However, if LPC acted inhomogeneously, the decreased magnitude of various membrane currents and increased membrane resistance may have been due to progressive reduction in the number of viable myocytes contributing to their electrical measurements as the irreversibly injured myocytes dropped out. Preserved electronic interactions with a population of less severely injured myocytes may still have been sufficient to account for the observed membrane depolarization until their electrotonic influence was also severed.

The ability of uninjured cells to prevent injured leaky cells from rapidly depolarizing might also account for the partial reversibility of the effects of LPC in multicellular preparations. In the example shown in Fig. $12 C$, an LPC-treated myocyte developed elevated diastolic $\mathrm{Ca}^{2+}$ when the membrane potential was held at $-40 \mathrm{mV}$, but diastolic $\mathrm{Ca}^{2+}$ returned to normal when the myocyte was repolarized to $-80 \mathrm{mV}$, presumably because of the more favorable electrochemical gradient for $\mathrm{Ca}^{2+}$ efflux via $\mathrm{Na}^{+}-\mathrm{Ca}^{2+}$ exchange (38). We hypothesize that in multicellular preparations with inhomogeneous injury, uninjured cells may protect the affected myocytes from sudden depolarization and rapid irreversible injury long enough for them to recover when LPC is washed out. In contrast isolated myocytes tend to deteriorate very rapidly once significant membrane leakiness develops. This is consistent with our observation that the effects of the nonspecific detergent saponin, like LPC, were irreversible in single myocytes, whereas in intact ferret papillary muscles the effects of saponin were reversible (50). However, in sheep Purkinje fibers saponin-induced membrane depolarization was also associated with an increase in intracellular $\mathrm{Na}^{+}$activity and a decrease in $\mathrm{K}^{+}$activity (50), whereas LPC has been shown to cause membrane depolarization in the absence of changes in intracellular $\mathrm{K}^{+}$activity (14). Thus we cannot exclude the possibility that LPC had specific effects on membrane currents in the multicellular heart unrelated to its detergent action.

It is more difficult to reconcile our findings with those of Kiyosue et al. $(19,20)$, who found that LPC depressed $I_{\mathrm{K} 1}$ at both the macroscopic and single-channel level in isolated patch-clamped guinea pig ventricular myocytes, and proposed this to be the major cause of membrane depolarization. However, these authors also found that LPC activated an additional current with a reversal potential near $0 \mathrm{mV}$, similar to our findings. Although we did not see any effect of LPC on $I_{\mathrm{K} 1}$ before activation of the latter current (Fig. 7), we could not exclude the possibility $I_{\mathrm{K} 1}$ was altered after this point.

Implications for ischemia. After coronary artery occlusion, ventricular arrhythmias are frequent during the first 20-30 min, after which they subside for 6-8 $\mathrm{h}$ before a late phase of arrhythmias begins (51). Whether lysophosphoglycerides accumulate rapidly enough to account for the early phase of arrhythmias remains controversial $(8-12,52-55)$. In addition to the issue of accurate quantitation of membrane lysophosphoglyceride content $(11,52)$, several factors may act synergistically with lysophosphoglycerides to enhance cardiac injury, such as acidosis (9) and oxygen-derived free radicals (56); conversely binding to albumin may increase the threshold of LPC required to cause injury. There may also be important intrinsic differences between the effects of exogenously applied lysophosphoglycerides and lysophosphoglyceride toxicity during ischemia. In the former case, lysophosphoglycerides are incorporated into normal cellular membranes. During ischemia, however, the lysophospholipids accumulate in cellular membranes whose phospholipid content has been altered, since the membrane phospholipids are the source of lysophospholipids generated via the action of phospholipase $A_{2}$ (11). Unfortunately the results of the present study do not directly help to resolve these controversies, and the extent to which these findings in isolated myocytes can be extrapolated to the intact heart remains speculative. Nevertheless, if the major effect of LPC during ischemia is to increase nonspecific membrane leakiness, then it seems unlikely that LPC accumulation has major effects during the early minutes of ischemia. Although the membrane rapidly depolarizes during early myocardial ischemia in response to extracellular $\mathrm{K}^{+}$accumulation, most studies show that the difference between the membrane potential and the $\mathrm{K}^{+}$ equilibrium potential $\left(E_{\mathrm{m}}-E_{\mathrm{K}}\right)$ progressively narrows over the first $15 \mathrm{~min}(57,58$; but see reference 59$)$, whereas an increase in nonspecific membrane permeability would be expected to widen $E_{\mathrm{m}}-E_{\mathrm{K}}$. A more likely role for lysophosphoglyceride toxicity is in the loss of membrane integrity that occurs after longer durations of ischemia, when reperfusion is associated with generalized membrane leakiness and cytosolic $\left[\mathrm{Ca}^{2+}\right]_{\mathrm{i}}$ overload leading to irreversible injury. A contribution of lysophosphoglyceride toxicity to the late phase of ventricular arrhythmias is also very possible. Further studies will be needed to elucidate these issues.

\section{Acknowledgments}

This study was supported by National Institutes of Health grants RO1 HL-36729 and RO1 HL-44880, by the Laubisch Cardiovascular Research Fund, and by a grant from the Flintridge Foundation. Dr. Liu was an American Heart Association Medical Student Research Fellow. Dr. Goldhaber is recipient of Clinician-Scientist Award 921-CS1 from the American Heart Association Greater Los Angeles Affiliate. Dr. Weiss is the recipient of National Institutes of Health Career Development Award HL-01890.

\section{References}

1. Liu, E., J. I. Goldhaber, and J. N. Weiss. 1990. Effect of lysophosphatidylcholine on adult guinea pig ventricular myocytes. Circulation. 82(Suppl. III):III520. (Abstr.)

2. Liu, E., J. I. Goldhaber, and J. N. Weiss. 1991. Effects of lysophosphatidylcholine on adult guinea pig ventricular myocytes. Clin. Res. 39:21 A. (Abstr.)

3. Downar, E., M. J. Janse, and D. Durrer. 1977. The effect of "ischemic" blood on transmembrane potentials of normal porcine ventricular myocardium. Circulation. 55:455-462. 
4. Liedtke, A. J. 1981. Alterations of carbohydrate and lipid metabolism in the acutely ischemic heart. Prog. Cardiovasc. Dis. 23:321-336.

5. Van der Vusse, G. J., and H. Stam. 1987. Lipid and carbohydrate metabolism in the ischemic heart. Basic Res. Cardiol. 82(Suppl. 1):149-153.

6. Van der Vusse, G. J., F. W. Prinzen, M. van Bilsen, W. Engels, and R. S. Reneman. 1987. Accumulation of lipids and lipid intermediates in the heart during ischemia. Basic Res. Cardiol. 82(Suppl. 1):157-167.

7. Liedtke, A. J. 1988. Lipid burden in ischemic myocardium. J. Mol. Cell Cardiol. 20(Suppl. 2):65-74.

8. Katz, A. M., and F. C. Messineo. 1981. Lipid-membrane interactions and the pathogenesis of ischemic damage in the myocardium. Circ. Res. 48:1-16.

9. Corr, P. B., R. W. Gross, and B. E. Sobel. 1984. Amphipathic metabolites and membrane dysfunction in ischemic myocardium. Circ. Res. 55:135-154.

10. Corr, P. B., J. E. Saffitz, and B. E. Sobel. 1987. Lysophospholipids, long chain acylcarnitines and membrane dysfunction in the ischaemic heart. Basic Res. Cardiol. 82(Suppl. 1):199-208.

11. Katz, A. M. 1982. Membrane-derived lipids and the pathogenesis of ischemic myocardial damage. J. Mol. Cell Cardiol. 14:627-632.

12. Corr, P. B., R. W. Gross, and B. E. Sobel. 1982. Arrhythmogenic amphiphilic lipids and the myocardial cell membrane. J. Mol. Cell Cardiol. 14:619626.

13. Arnsdorf, M. F., and G. J. Sawicki. 1981. The effects of lysophosphatidylcholine, a toxic metabolite of ischemia, on the components of cardiac excitability in sheep purkinje fibers. Circ. Res. 49:16-30.

14. Clarkson, C. W., and R. E. Ten Eick. 1983. On the mechanism of lysophosphatidylcholine-induced depolarization of cat ventricular myocardium. Circ. Res. 52:543-556.

15. Corr, P. B., M. E. Cain, F. X. Witkowski, D. A. Price, and B. E. Sobel. 1979. Potential arrhythmogenic electrophysiological derangements in canine purkinje fibers induced by lysophosphoglycerides. Circ. Res. 44:822-832.

16. Corr, P. B., D. W. Snyder, M. E. Cain, W. A. Crafford, Jr., R. W. Gross, and B. E. Sobel. 1981. Electrophysiological effects of amphiphiles on canine purkinje fibers: implications for dysrhythmia secondary to ischemia. Circ. Res. 49:354-363.

17. Corr, P. B., D. W. Snyder, B. I. Lee, R. W. Gross, C. R. Keim, and B. E. Sobel. 1982. Pathophysiological concentrations of lysophosphatides and the slow response. Am. J. Physiol. 243 (Heart Circ. Physiol. 12):H187-195.

18. Pogwizd, S. M., J. R. Onufer, J. B. Kramer, B. E. Sobel, and P. B. Corr. 1986. Induction of delayed afterdepolarizations and triggered activity in canine purkinje fibers by lysophosphoglycerides. Circ. Res. 59:416-426.

19. Kiyosue, T., and M. Arita. 1986. Effects of lysophosphatidylcholine on resting potassium conductance of isolated guinea pig ventricular cells. Pflügers Arch. Eur. J. Physiol. 406:296-302.

20. Kiyosue, T., M. Aomine, and M. Arita. 1984. Lysophosphatidylcholine decreases single channel conductance of inward rectifier $\mathrm{K}^{+}$channel in mammalian ventricular myocytes. Jpn. J. Physiol. 34:369-373.

21. Sedlis, S. P., P. B. Corr, B. E. Sobel, and G. G. Ahumada. 1983. Lysophosphatidyl choline potentiates $\mathrm{Ca}^{2+}$ accumulation in rat cardiac myocytes. $\mathrm{Am}$. J. Physiol. 244 (Heart Circ. Physiol. 13):H32-H38.

22. Sedlis, S. P., J. M. Sequeira, G. G. Ahumada, and N. E. Sherif. 1988. Effects of lysophosphatidylcholine on cultured heart cells: correlation of rate of uptake and extent of accumulation with cell injury. J. Lab. Clin. Med. 112:745754

23. Burnashev, N. A., A. I. Undrovinas, I. A. Fleidervish, and L. V. Rosenshtraukh. 1989. Ischemic poison lysophosphatidylcholine modifies heart sodium channels gating inducing long-lasting bursts of openings. Pflügers Arch. Eur. J. Physiol. 415:124-126.

24. Kim, D., and R. A. Duff. 1991. Regulation of $\mathrm{K}^{+}$channels in cardiac myocytes by free fatty acids. Circ. Res. 67:1040-1046.

25. Mitra, R., and M. Morad. 1986. A uniform enzymatic method for dissociation of myocytes from hearts and stomachs of vertebrates. Am. J. Physiol. 249 (Heart Circ. Physiol. 18):H1056-H1060.

26. Hamill, O. P., A. Marty, E. Heher, B. Sakmann, and F. J. Sigworth. 1981. Improved patch-clamp techniques for high-resolution current recording from cells and cell-free membrane patches. Pflügers Arch. Eur. J. Physiol. 391:85-100.

27. Carbone, E., and H. D. Lux. 1987. Kinetics and selectivity of a low voltage activated calcium current in chick and rat sensory neurons. J. Physiol. (Lond.). 386:547-570.

28. Callewaert, G., L. Cleemann, and M. Morad. 1988. Epinephrine enhances $\mathrm{Ca}^{2+}$ current regulated $\mathrm{Ca}^{2+}$ release and $\mathrm{Ca}^{2+}$ reuptake in rat ventricular myocytes. Proc. Natl. Acad. Sci. USA. 85:2009-2013.

29. Grynkiewicz, G., M. Poenie, and R. Tsien. 1985. A new generation of $\mathrm{Ca}^{2+}$ indicators with greatly improved fluorescence properties. J. Biol. Chem. 260:3440-3450.

30. Steadman, B. W., K. B. Spitzer, and J. H. B. Bridge. 1988. A video system for measuring motion in contracting heart cells. IEEE Trans. Biomed. Eng. 35:264-272.

31. Colquhoun, D., E. Neher, H. Reuter, and C. F. Stevens. 1981. Inward current channels activated by intracellular calcium in cultured cardiac cells. $\mathrm{Na}$ ture (Lond.). 294:752-754
32. Fedida, D., D. Noole, A. C. Renkin, and A. J. Spindler. 1987. The arrhythmogenic transient inward current $i_{T 1}$ and related contraction in isolated guineapig ventricular myocytes. J. Physiol. (Lond.). 392:523-542.

33. Hagiwara, N., H. Irasawa, and M. Kameyama. 1988. Contribution of two types of calcium currents to the pacemaker potentials of rabbit sino-atrial node cells. J. Physiol. (Lond.). 395:233-253.

34. Bean, B. P. 1985. Two kinds of calcium channels in canine atrial cells. $J$. Gen. Physiol. 86:1-30.

35. Nilius, B., P. Hess, J. B. Lansman, and R. W. Tsien. 1985. A novel type of cardiac calcium channel in ventricular cells. Nature (Lond.). 316:443-446.

36. Mitra, R., and M. Morad. 1986. Two types of calcium channels in guinea pig ventricular myocytes. Proc. Natl. Acad. Sci. USA. 83:5340-5344.

37. Callewaert, G. L. Cleeman, and M. Morad. 1989. Caffeine-induced $\mathrm{Ca}^{2+}$ release activates $\mathrm{Ca}^{2+}$ extrusion via $\mathrm{Na}^{+}-\mathrm{Ca}^{2+}$ exchanger in cardiac myocytes. $\mathrm{Am}$. J. Physiol. 257 (Cell Physiol. 26):C147-C152.

38. Bridge, J. H. B., K. W. Spitzer, and P. R. Ershler. 1988. Relaxation of isolated ventricular cardiomyocytes by a voltage-dependent process. Science (Wash. DC). 241:823-825.

39. Weltzien, H. U. 1979. Cytolytic and membrane-perturbing properties ysophosphotidylcholine. Biochim. Biophys. Acta. 559:259-287.

40. Bergmann, S. R., T. B. Ferguson Jr., and B. E. Sobel. 1981. Effects of amphiphiles on erythrocytes, coronary arteries, and perfused hearts. Am. J. Physiol. 240 (Heart Circ. Physiol. 9):H229-H237.

41. Stafford, R. E., T. Fanni, and E. A. Dennis. 1989. Interfacial properties and critical micelle concentration of lysophospholipids. Biochemistry. 28:51135120 .

42. Lee, Y., and S. I. Chan. 1977. Effect of lysolecithin on the structure and permeability of lecithin bilayer vesicles. Biochemistry. 16:1303-1309.

43. Reiss-Husson, F. 1967. Structure des phases liquide-cristallines de différents phospholipides, monoglycerides, sphingolopides, anhydres ou en présence d'eau. J. Mol. Biol. 25:363-382.

44. Kim, D., and D. E. Clapham. 1989. Potassium channel in cardiac cells activated by arachidonic acid and phospholipids. Science (Wash. DC). 244:11741176

45. Kameyama, M., K. Kakei, R. Sato, T. Shibasaki, H. Matsuda, and H. Irisawa. 1984. Intracellular $\mathrm{Na}^{+}$activates a $\mathrm{K}^{+}$channel in mammalian cardiac cells. Nature (Lond.). 309:354-356

46. Bersohn, M. M., K. D. Philipson, and R. S. Weiss. 1983. Lysophosphatidylcholine and sodium-calcium exchange in cardiac sarcolemma: comparison with ischemia. Am. J. Physiol. 260 (Cell Physiol. 29):C433-C438.

47. Brovkovitch, V. M., Y. V. Nikitchenko, and V. V. Lemeshko. 1987. The damage of $\mathrm{Ca}^{2+}$-transporting function and lipid membrane component of the sarcoplasmic reticulum in total ischemia of the rat myocardium. Byull. Eksp. Biol. Med. 104:546-548.

48. Ambudkar, I. S., E. S. Abdallah, and A. E. Shamoo. 1988. Lysophospholipid-mediated alterations in the calcium transport systems of skeletal and cardiac muscle sarcoplasmic reticulum. Mol. Cell. Biochem. 79:81-89.

49. Oishi, K., B. Zheng, and J. F. Kuo. 1990. Inhibition of Na,K-ATPase and sodium pump by protein kinase $\mathrm{C}$ regulators sphingosine, lysophosphatidylcholine, and oleic acid. J. Biol. Chem. 265:70-75.

50. Noireaud, J., C. M. Bright, and D. Ellis. 1989. Effects of saponin on contractile force and intracellular ion activities in cardiac tissues. J. Mol. Cell. Cardiol. 21:291-298.

51. Janse, M. J., and A. L. Wit. 1989. Electrophysiological mechanisms of ventricular arrhythmias resulting from myocardial ischemia and infarction. Physiol. Rev. 69:1049-1169.

52. Shaikh, N. A., and E. Downar. 1981. Time course of changes in porcine myocardial phospholipid levels during ischemia: a reassessment of the lysolipid hypothesis. Circ. Res. 49:316-325.

53. Snyder, D. A., W. A. Crafford, Jr., J. L. Glashow, D. Rankin, B. E. Sobel, and P. B. Corr. 1981. Lysophosphoglycerides in ischemic myocardium effluents and potentiation of their arrhythmogenic effects. Am. J. Physiol. 241 (Heart Circ. Physiol. 10):H700-H707.

54. Corr, P. B., K. A. Yamada, M. H. Creer, A. D. Sharma, and B. E. Sobel. 1987. Lysophosphoglycerides and ventricular fibrillation early after onset of ischemia. J. Mol. Cell Cardiol. 19(Suppl. V):45-53.

55. Kinnaird, A. A. A., P. C. Choy, and R. Y. K. Man. 1988. Lysophosphatidylcholine accumulation in the ischemic canine heart. Lipids. 23:32-35.

56. Mak, I. T., J. H. Kramer, and W. B. Weglicki. 1986. Potentiation of free radical-induced lipid peroxidative injury to sarcolemmal membranes by lipid amphiphiles. J. Biol. Chem. 261:1153-1157.

57. Kleber, A. G. 1983. Resting membrane potential, extracellular $\mathrm{K}^{+}$activity and intracellular $\mathrm{Na}^{+}$activity during global ischemia in isolated perfused guinea pig hearts. Circ. Res. 52:442-450.

58. Weiss, J. N., and K. I. Shine. 1986. Effects of heart rate on extracellular $\left[\mathrm{K}^{+}\right]$accumulation during myocardial ischemia. Am. J. Physiol. 250 (Heart Circ. Physiol. 19):H982-H991.

59. Blake, K., W. T. Clusin, M. R. Franz, and N. A. Smith. 1988. Mechanism of depolarization in the ischaemic dog heart: discrepancy between $\mathrm{T}-\mathrm{Q}$ potentials and potassium accumulation. J. Physiol. (Lond.). 397:307-330. 